\title{
Essays on Indonesian Undernutrition Vulnerability and Domestic Asymmetric Rice Price Transmission with the World
}

\section{Dissertation}

to obtain the Ph. D. degree

in the International Ph. D. Program for Agricultural Sciences in Goettingen (IPAG) at the Faculty of Agricultural Sciences,

Georg-August-University Göttingen, Germany

presented by

\section{Farah Wulandari Pangestuty}

born in Indonesia 
D7

Name of supervisor: Prof. Xiaohua Yu, Ph.D.

Name of co-supervisor: $\quad$ Prof. Stephan Klasen, Ph.D.

Name of co-supervisor: Prof. Dr. Bernhard Brümmer

Date of dissertation: $15^{\text {th }}$ November 2018 


\section{ACKNOWLEDGEMENT}

Being a wife and a mom while pursuing a Ph.D. degree, for me, is indescribable challenging priceless experience. This journey has taught me about life, genuine camaraderie, hard work and perseverance I cannot imagine before, which strengthening and enlightening me. The completion of this dissertation is possible with the support of several important people who I am grateful to have them around me. Words are never enough to express my gratitude to them who have helped me in many ways.

Firstly, I would like to express my sincere gratitude to my supervisor, Prof. Xiaohua Yu for the opportunity to grow within an incredible group of scientists and researchers. His dedication through managing and maintaining a Thursdays group discussion is one of many proofs that he has been super serious in giving his immense knowledge. I cannot thank him enough for the time, help, and patience he has given me. My sincere thanks also goes to Prof. Stephan Klasen and Prof Bernhard Brümmer for the valuable insights, comments and suggestions for my dissertation improvements.

My special thanks goes to Prof. Matin Qaim, Dr. Melanie Grosse, and all of my colleague in GlobalFood. This diverse group of researchers has taught me many valuable lessons through very well designed courses that are very useful for the continuation of my future career. I also would like to thank to my colleague in the chair of Prof. Yu: Tahir, Feifei, Eva, Dieter, Christoph and Tri, you are the best mentor I have ever had. I will never forget your sincere help during my hard time to understand the papers I had to present. Jana Nowakowsky is more than my Prof's secretary for me. She has helped me from the beginning to the end of this journey in whatever issue I had. I thank her very much for her warmth and friendliness.

I especially thank to my family i.e. my husband, my children, and our parents who give us endless supports and prays throughout my years of study. My extended thank also goes to my Indonesian family in KALAM Göttingen and Indonesian student association which makes Göttingen feels like Malang (my home town), Wak Tiny Klein and Budhe Atiet who encourage us through their life stories and example. Only God who can pay for all of the kindheartedness. I also gratefully thank to my Quranic teacher Nouman Ali Khan from Bayyinah Institute who has introduced me to an exploration of the content of the Quran and its applications as a guidance to ensure the completion of this Ph.D. journey.

Last but not least. I would like to extend my heartfelt thanks to the Ministry of Research, Technology, and Higher Education of the Republic of Indonesia for awarding me the postgraduate scholarship, University of Brawijaya for the financial support during finishing this dissertation, and Georg-August-Universitát Göttingen for the opportunity to pursue my doctoral degree.

Above all, my praises and thanks only for ALLAH, the Almighty, the Giver of bountiful blessings and gifts, for granting me everything that I need to accomplish this Ph.D. degree. 
"And if whatever trees upon the earth were pens and the sea [was ink], replenished thereafter by seven [more] seas, the words of ALLAH would not be exhausted. Indeed, ALLAH is Exalted in Might and Wise"

(Quran Surah Luqman (31): 27) 


\section{SUMMARY}

This dissertation addresses two different aspects related to food security problems in Indonesia, particularly from the aspect of food accessibility and availability.

The first essay deals with the assessment of undernutrition vulnerability, in which we highlight the importance of assessing the probability of being nutrient deficient in the near future as a complement to the current nutritional status. The empirical investigation is conducted by employing the Just and Pope (1979) method to estimate the vulnerability rate across households. By exploiting the households' socioeconomic characteristics and district specific information, the study finds that income is the most prominent indicator in determining the sufficiency of nutrient intake. Moreover, two micronutrient-related variables are educational background and the health facilities provided in the region. Higher educational background and a greater number of health facilities are correlated with higher micronutrient consumption and lower macronutrient intake. In terms of district-specific variables, the number of clinics and markets play a positive role in decreasing the vulnerability rate to undernutrition. In addition, the probability of being vulnerable to undernutrition is considered as high in the sample with current status of fully nourished. One third from around $46 \%$ food secured sample households are found to be vulnerable to under consumption of calorie. While approximately $14 \%$ out of $41 \% .13 \%$ out of $50 \%, 6 \%$ out of $60 \%$ households with nourished nutritional status are found to be vulnerable in terms of inadequate intake of protein, calcium, and iron respectively.

The subsequent essay aims at examining the transmission of the international rice price (Thailand and Vietnam price as the reference price) movements to the domestic price. As a big rice imported country, Indonesia is prone to the shock from the international market, given the thin feature of the world rice market. We test whether the error adjust asymmetrically by applying Vector Error Correction Model with ECM being split as well as the threshold effect (Threshold Vector Error Correction Model). The findings reveal that there is low price transmission from international to domestic rice market, with asymmetric adjustment of error. We find the threshold effect only for Indonesia-Thailand price pair. 


\section{TABLE OF CONTENTS}

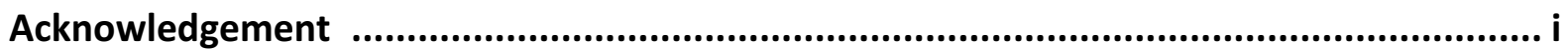

Summary ............................................................................................................................. iii

Table of Contents ....................................................................................................................iv

List of Tables and Figures................................................................................................ v

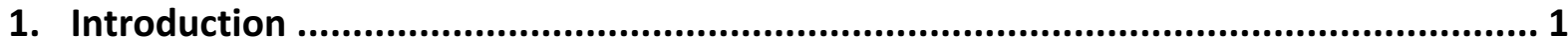

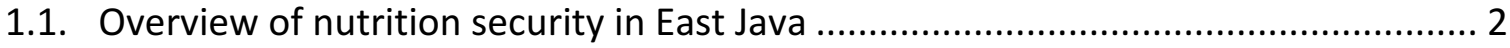

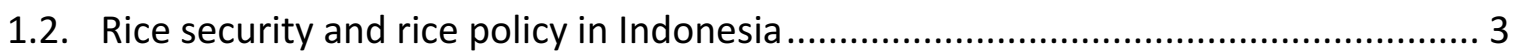

1.3. Research objectives and outline of the dissertation ......................................... 5

2. Assessing Vulnerability to Undernutrition in Indonesia ......................................... 6

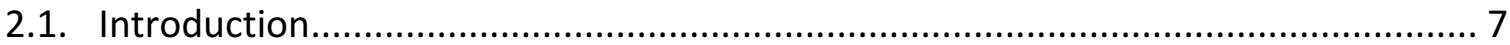

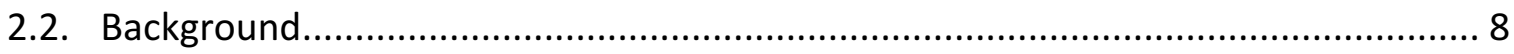

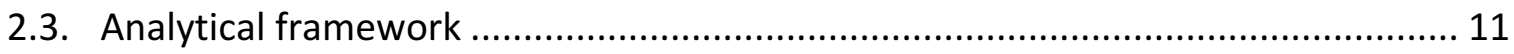

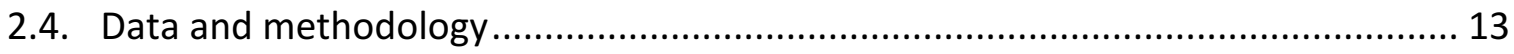

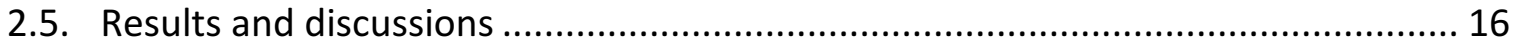

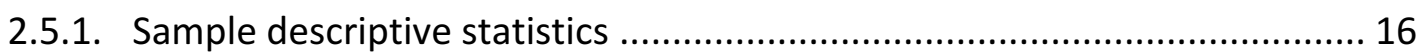

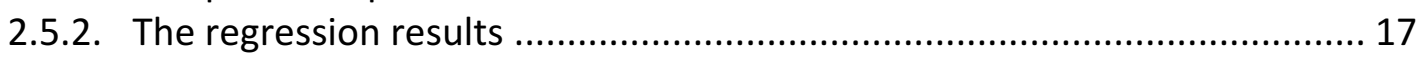

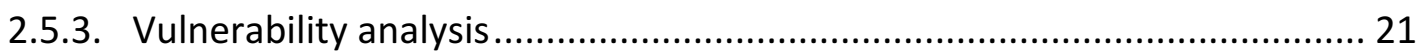

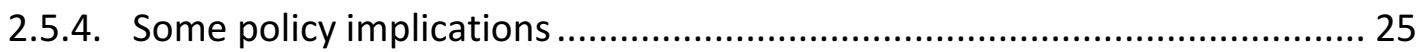

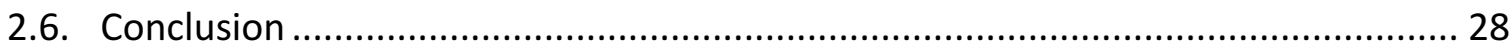

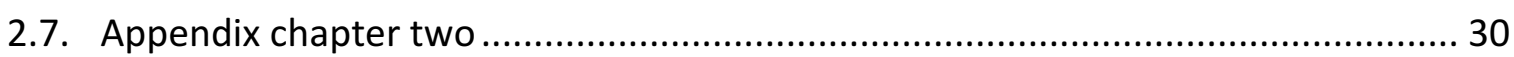

3. Market Integration between Indonesian Rice Market and the World ....................... 45

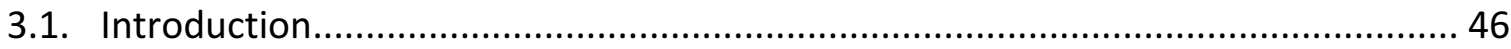

3.2. Rice national supply balance and the polemic of import policy........................... 49

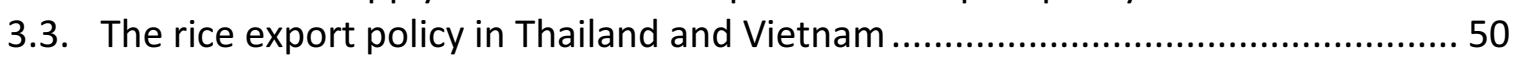

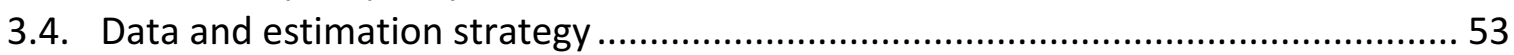

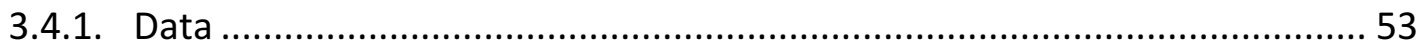

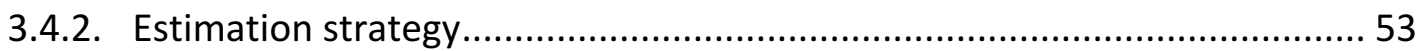

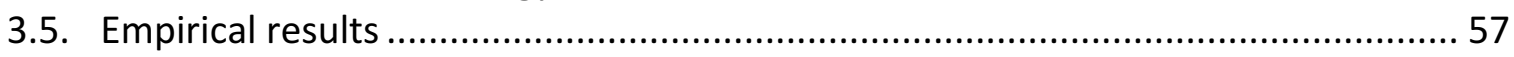

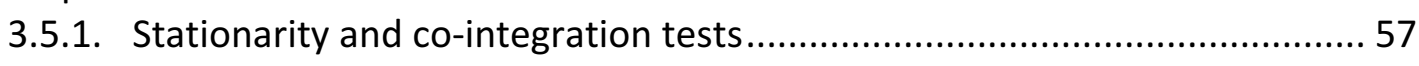

3.5.2. Symmetric, asymmetric, and threshold error correction model ................ 58

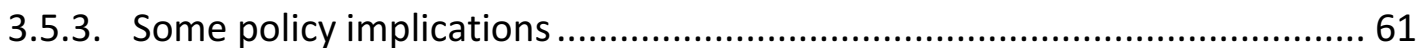

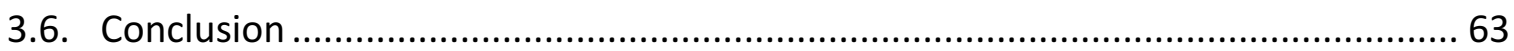

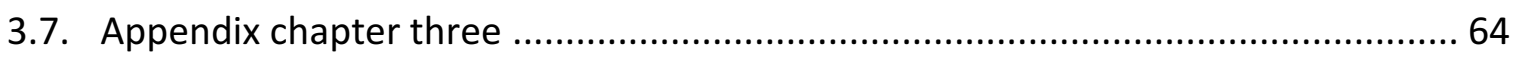

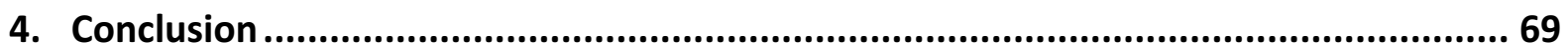

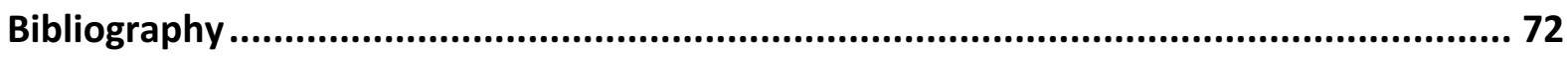




\section{LIST OF TABLES AND FIGURES}

Table 2.1. East Java Province's Socio and Economic Performance ........................................ 30

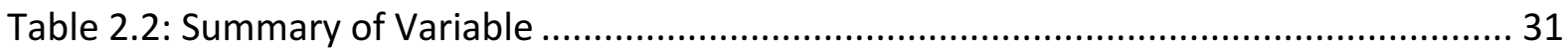

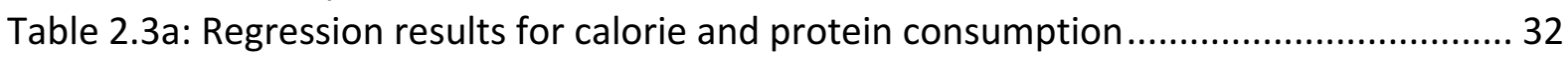

Table 2.3b: Regression results for calcium and iron consumption ...................................... 33

Table 2.4a: Descriptive statistics of household characteristics based on their four quadrant

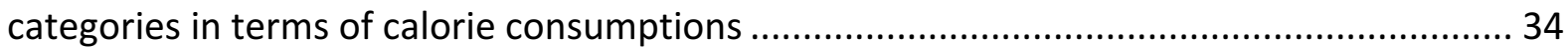

Table 2.4b: Descriptive statistics of household characteristics based on their four quadrant

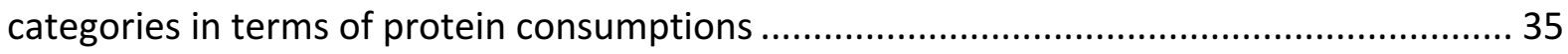

Table 2.4c: Descriptive statistics of household characteristics based on their four quadrant

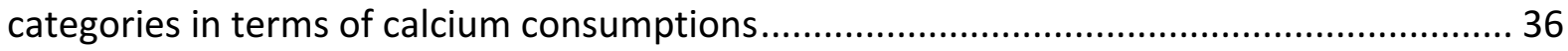

Table 2.4d: Descriptive statistics of household characteristics based on their four quadrant

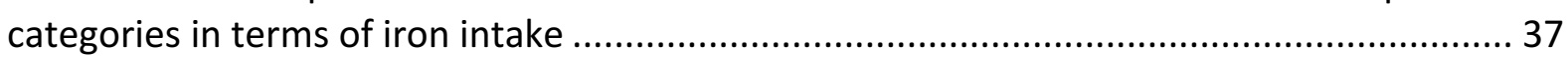

Table 2.5. Current status of food security and its prediction of vulnerability...................... 38

Table 2.6. Levels of vulnerability to food insecurity - relationships with selected variables. 39

Table 2.7. Dietary Reference Information 2013 ........................................................... 41

Table.3.1: Summary Statistics for The Investigated Price Variables in USD .......................... 64

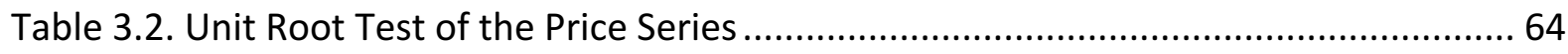

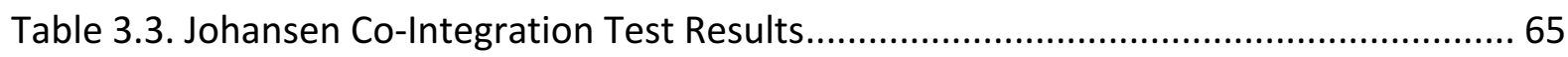

Table 3.4a. Results of Vector Error Correction Model: Domestic - World............................ 65

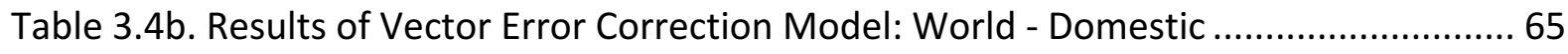

Table 3.5. Results of the Asymmetric ECM ..................................................................... 66

Table 3.6. Test of Linear Co-Integration Versus Threshold Co-Integration by Hansen and Seo

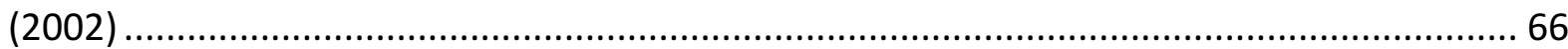

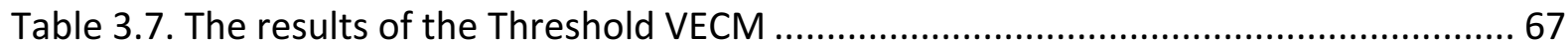

Figure 2.1. Comparison between National and East Java Growth Rate (in percentage)....... 42

Figure 2.2. Comparison between National and East Java Poverty Rate (in percentage) ....... 42

Figure 2.3. Conceptual Framework of Vulnerability to Future Food Insecurity ................... 43

Figure 2.4: Distributions of average daily nutrition consumptions and its prediction values 44

Figure 3.1. The quantity of rice productions, consumptions, and imports $2010-2017 \ldots . . .68$ 


\section{CHAPTER ONE}

\section{INTRODUCTION}

Indonesia is the fourth most densely populated country after China, India, and the USA, with 262 million inhabitants (Statistics Indonesia, 2018). From 2010 to 2017, population growth has touched 1.3\% per year (Statistics Indonesia, 2018). Considering this, McDonald (2014) estimated that the population of Indonesia would approach 300 million in 2035 . This can be viewed as an immense opportunity to achieve many economic goals; however, it also creates pressure on the limited natural resources (e.g., agricultural production and land), increases the unemployment rate bringing with it inequality in income distribution and the issue of poverty, and ultimately, presents a challenge to actualize sustainable food security.

The 1998 multidimensional crisis caused a sharp rise in the poverty rate of Indonesia from around $11 \%$ to $24 \%$ (Statistics Indonesia, 2002). Coupled with the high inflation level, there was a considerable decline in purchasing power, with the poor becoming unable to afford food. Since then, the problem of malnutrition became pervasive in the country and food security became a matter of urgency until recently. Specifically, a country is said to have food security "when all people, at all times, have physical and economic access to sufficient, safe, and nutritious food to meet their dietary needs and food preferences for an active and healthy life" (Pinstrup-Anderson, 2009). The four pillars on which food security is built are physical availability of food, economic and physical access to food, food utilization, and stability of the other dimensions over time (FAO, 2008). This dissertation aims to provide evidence related to the first and second pillars in the context of Indonesia. 
The first segment (chapter two) examines East Java, one of the most productive provinces in terms of rice, cassava, and maize, and showing high performance in terms of macroeconomic variables (e.g., a relatively high Gross Domestic Product (GDP) and massive development in infrastructure). Despite this, poverty and malnutrition are chronic in this province. The concern about insufficient food access at the household level is examined by studying the vulnerability to nutrition deficiency using household characteristics and district-specific information.

The next segment (chapter three) points to the first pillar, that is, food availability. Here, we focus on the availability of rice throughout the country (we use national data for this assessment), which is a prominent aspect of society, notably because rice is the staple food for most Indonesians and makes up approximately $70 \%$ of the main source of calorie intake. In this sense, food security is more about rice security in the country. To this end, a price transmission analysis is conducted to understand the behavior of the domestic price of rice in association with the movement of its international price. This is important for the domestic economy because since the end of the oil boom (in early 1980s), Indonesia has considerably increased its import of rice to stabilize the domestic price. Any shock from the international market would potentially exacerbate the situation in the domestic economy.

\subsection{Overview of nutrition security in East Java}

East Java is a province in the eastern part of the island of Java. It has a total area of $47,799.75$ square kilometers with a population of around 41 million (Statistics Indonesia, 2015). Thus, East Java is the second most populous province after Jakarta, the nation's capital. Owing to its geographical contour, the soil is fertile and, therefore, this province is the second largest producer of paddy, cassava, and corn after Central Java (Dewan Ketahanan Pangan, Kementerian Pertanian, and World Food Programme, 2015).

The agricultural sector accounts for around $23 \%$ of its GDP and around $38 \%$ of the people earn their livelihood from this sector. The infrastructure of the province is relatively good; roads and bridges connect $90 \%$ of the area and $54 \%$ of the population gained access to clean water and improved sanitation in 2011, which improved to around $70 \%$ in 2015; and the female illiteracy rate was around 13\% in 2015 (Statistics Indonesia, 2017). 
Despite its economic performance, poverty and undernutrition remains an issue in East Java. Poverty alleviation programs have shown some improvements over the last five years. However, the poverty gap index, which shows the depth of poverty compared to the poverty line, has shown no progress (Statistics Indonesia, 2017), and the inequality in income distribution increased from 0.35 in 2008 to 0.42 in 2015 (Arif and Wicaksani, 2017). The World Bank (2018) states that around $40 \%$ of the population lives just above the poverty line. Thus, any economic instability, for example, rising inflation rate, or any political instability that causes the price of staples to rise can endanger these vulnerable people.

Further, of the 28 districts in East Java, nine are categorized as moderately vulnerable and as priority group 3 (Dewan Ketahanan Pangan, Kementerian Pertanian, and World Food Programme, 2015). In this category, stunting among children is around 40\%; moreover, more than $15 \%$ of the infants are found to be undernourished every year, on average. Compared to Papua and East Nusa Tenggara (two provinces in the eastern part of Indonesia, which have poorer infrastructural conditions, higher rates of illiteracy, and poorer people than those in East Java), some districts in East Java have relatively the same level of stunting among children (44.2\% in Papua and 46\% in East Nusa Tenggara). Despite the moderate vulnerability status of these nine districts, most of the districts and cities in East Java have children with chronic nutrition deficiency (Dewan Ketahanan Pangan, Kementerian Pertanian, and World Food Programme, 2015).

\subsection{Rice security and rice policy in Indonesia}

For Indonesians, food security is tantamount to rice security due to the latter's importance in people's diet as well as it being a source of income for producers and traders. In 2014, 11\% of household budget was allocated to buying rice, on average. However, for the poor, this can reach up to $30 \%$ to $35 \%$ (Statistics Indonesia, 2015). Consequently, achieving a reasonable, affordable, and stable rice price is the government's overriding objective in every policy decision as the price of rice potentially has a huge impact on the poor as reflected in the macroeconomic variables of inflation and poverty rate. As such, the poor in the rural areas are among the most vulnerable to rice price instability. 
Adequate domestic rice production is, therefore, among the most crucial factors in keeping the price of rice stable and in ensuring rice security throughout the country. Infrastructure that promotes rice production, including credit institutions (e.g., Kredit Usaha Rakyat from Bank Rakyat Indonesia), research and development, agricultural extension, and regulations, have been established to support the dynamics of Indonesian rice production. Indonesia has passed at least three of the most fundamental phases of policy in accordance with the rice production. In the New Order era, when Indonesia benefited from the rising oil prices (19791982), the government heavily supported rice production (i.e., through irrigation and input subsidies), leading to rapid acceleration in rice production nationally. Soon after the end of the oil boom, the government no longer received revenues from the increase in oil prices and support for rice production decreased gradually along with a deceleration in rice production until the 1997 crisis (McCulloch and Timmer, 2008). The third phase was marked by the declaration of agriculture revitalization in 2005, whereby rice production regained its importance in the government policy agenda. However, rice self-sufficiency had not been achieved, until recently.

Further, during the first and second phases, BULOG (the national logistic planning agency) played an important role as it received an explicit price stabilization mandate and import monopoly (Timmer, 2006). Through a combination of policies, BULOG succeeded in creating food security. It sourced rice from farmers and imports, and maintained a certain amount of rice as a buffer and released it to manipulate the market price. Unfortunately, BULOG collapsed when the 1997 crisis emerged because of corruption within the institution (Yonekura, 2005). Privatization and revocation of monopoly rights then became the inevitable choice to overcome the huge operational costs of BULOG. Furthermore, from 1999, rice price stabilization was achieved through private trade. Since then, the price of rice has stayed rigidly above the international price. This has left Indonesia in an import trap, and therefore, the strategy to achieve food security needs modification

Since 1999, rice from the international market has become more crucial for the price stabilization policy. Indonesia's dependency on rice import predominantly makes the position of Thailand and Vietnam as the main rice suppliers important. The thinness feature of the international rice market highlights the importance of studying the domestic price movement 
in accordance with the movements (shocks) from other markets. Therefore, part of this dissertation is dedicated to shedding light on aspects related to price transmission and market integration of rice between the international and the domestic market (chapter three).

\subsection{Research objectives and outline of the dissertation}

In accordance with the description outlined above, this dissertation tries to address two different aspects of the food security issue related to food accessibility and food availability. The first segment (chapter two) is about the importance of understanding and measuring the index of vulnerability to nutrition deficiency. We explore household characteristics and district-specific information to construct the vulnerability index using an Indonesian household socioeconomic survey and village potential data of 2013 provided by Statistics Indonesia. This segment of the study aims to explore the vulnerability of the households in East Java to energy, protein, and micronutrient intake adequacy.

The second segment (chapter three) examines the relationships between the international rice markets and the domestic economy. We use Thailand's and Vietnam's prices as reference since these two countries are the largest rice exporters globally. This segment of the study aims to provide a better understanding of the error correcting behavior when there are movements in the reference price to the domestic price as well as the impact of shocks from the international market on the domestic economy.

The remainder of the dissertation is structured as follows. Chapter 2 assesses undernutrition vulnerability in East Java, Indonesia. Chapter 3 examines market integration between the international and domestic rice markets. Chapter 4 summarizes the policy implications of the findings and highlights some limitations and directions for future research. 


\title{
CHAPTER TWO
}

\section{ASSESSING VULNERABILITY TO UNDERNUTRITION IN INDONESIA}

\begin{abstract}
This study aims to analyze the level of vulnerability to undernutrition in Indonesia, uncovering the fact that a large number of people are still prone to insufficient intake of calories, protein, calcium, and iron, despite the country's economic development. Data from the East Java socioeconomic household survey of 2013 are used, and the methods of Just and Pope (1979) are employed to measure vulnerability to calories, protein, calcium, and iron consumption, based on household-specific and district characteristics. Further, an undernutrition vulnerability index is constructed to capture the level of nutrition deficiency in this region. From the regression analysis, we find that income has the most significant effect on calories, protein, calcium, and iron consumption. Moreover, two micronutrient-related variables are educational background and the health facilities provided in the region. Higher educational background and a greater number of health facilities are correlated with higher micronutrient consumption and lower macronutrient intake. We propose that improving the food pyramid concept and implementing it in everyday life is crucial. In terms of the vulnerability level, it is evident that half the people in the sample are vulnerable to nutrition deficiency. In the sample of well-nourished people, $15 \%$ are vulnerable to under-consumption of calories, $13 \%$ to protein, $12 \%$ to calcium, and $6 \%$ to iron, which cannot be captured by the current nutritional status. This implies that policy should target the vulnerable instead of only focusing on the current poor as part of welfare dynamics.
\end{abstract}




\subsection{Introduction}

There have been extensive discussions about how nutrition is one of the key elements for a country's sustainable development. Some studies empirically show that better nutrition has links to permanent economic growth through various paths (Strauss, 1998; Arora, 2001). Health and productivity represent channels from which nutrition leads to better economic performance. Admittedly, a well-nourished society is a form of human capital investment, which has a pivotal effect on economic development both in the short and long term. Unfortunately, not all countries can achieve an adequate investment in human capital to support their development processes, especially in the case of developing countries such as Indonesia.

Despite its immense economic growth during the last century, hunger and malnutrition remain a catastrophic phenomenon in Indonesia. Chronic energy, protein, and micronutrient deficiencies remain a public health problem and exist in some form or the other throughout the country (Atmarita, 2005; Dewan Ketahanan Pangan, Kementerian Pertanian, and World Food Programme, 2015). Statistics show that, from 2007 to 2013, around 37\% of the children suffered from stunted growth, $13.3 \%$ were wasted, and $17.9 \%$ were underweight (Departemen Kesehatan Republik Indonesia, 2013; FAO, 2015). Additionally, 87 million Indonesians were food insecure and nearly 20 million people went to bed hungry everyday (FAO, 2015; World Food Programme, 2014). These numbers are a serious concern. In the case of micronutrient deficiency, Hartini et al. (2003) pointed out that the intake of calcium, especially in pregnant women, is lower than the Estimated Average Requirements (EAR) value. They show that $70 \%$ of pregnant women who are in their third trimester are at risk of inadequate intake of calcium, iron, and vitamin A. This condition worsened toward the crisis period of 1996-1998. Radix et al. (2012) pointed out that the rate of malnourishment with respect to iron and zinc is very high in the population. Iron deficiency stood at $38 \%$ among young adults, $26 \%$ in children, and $11 \%$ in the adolescent population. In terms of zinc deficiency, the numbers were doubled with $64 \%$ young adults, $60 \%$ children, and $45 \%$ adults suffering from zinc deficiency. Some policy implementations may have a positive impact in improving one's nutritional status (FAO, 2013). However, the persistent high rate of malnutrition, revealed by the aforementioned studies, signal that the nutritional status of an individual is temporary. 
The nutritional status of an individual is more a dynamic than a static concept (Capaldo, 2010; Scaramozzino, 2006). Commonly, individuals with poor access to economic resources face uncertainty in getting nutritious food on a daily basis, which leaves them in and out of a state of undernutrition. In other words, there is a possibility that an individual with good nutrient intake could become undernourished in the near future due to various shocks. Permanent access to sufficient, safe, and nutritious food is a prerequisite for a person to be considered "food secure" or "well-nourished" according to the first World Food Summit. These circumstances present challenges for policy makers to respond to the future livelihood of society, especially of vulnerable groups that are economically weak due to lack of access to economic resources. Hence, a vulnerability analysis is needed to capture the dynamic sense of nutritional status of an individual to produce better policy formulation.

Current nutrition status is an ex post analysis, which cannot provide ex ante policy implications for undernourishment. In contrast, a vulnerability analysis involves quantitatively estimating the likelihood of a given household experiencing degradation of nutrient intake due to a sudden unexpected event. Moreover, it utilizes household characteristics to predict the near-future condition. Then, from this process, households can be classified as vulnerable or secure.

\subsection{Background}

There are at least two aspects concerning the importance of vulnerability analysis. First, many studies show that in a country where undernutrition prevails, the problem of obesity will follow (double burden problem). ${ }^{1}$ These two problems are transmitted through agricultural policies that tend to provide high calorie but low nutrition food, leading to an overfed and undernourished situation. Further, non-communicable diseases resulting from obesity possibly become the next serious problem to be tackled. Second, a wide range of studies by the World Bank reveals that it is possible to prevent undernutrition at a very low cost (Horton, 2001; Horton et al., 2009). Vitamin A supplementation and iodization have been evidently significant in improving malnourished children. These two benefits provide the link that

\footnotetext{
${ }^{1}$ Ecker et al. (2016); Prentice (2006)
} 
highlights the importance of vulnerability analysis, which can clarify the dynamic aspects of the nutritional condition of an individual by making it observable. In addition, improving the underlying socioeconomic determinants is not often followed by enhancement of nutritional status.

Considering the benefits and low-cost prevention method to overcome nutrition deficiency, this research aims to examine the vulnerability of undernutrition in Indonesia using East Java province survey data for 2013.

East Java is a province in the east of Java Island, which has a good socioeconomic performance. Since the 2000s, it has had a moderate and stable growth rate, and it contributes significantly to the national economy (Table 2.1). Moreover, in the last five years (2012-2016), East Java's growth rate has been above the national level (Figure 2.1). More importantly, this province is the main producer of prominent crops within the country, such as rice, maize, and cassava, and therefore, it plays a significant role in the context of food security.

(Insert Table 2.1)

(Insert Figure 2.1)

However, despite its macroeconomic achievements, the population of poor living in this province is the highest in the country as of 2017, exceeding the national level (Figure 2.2). Furthermore, the number of illiterate women and the Gini ratio has shown no progress over the five-year period from 2011 to 2014 (Dewan Ketahanan Pangan, Kementerian Pertanian, and World Food Programme, 2015). In addition, the prevalence of undernutrition, particularly among children under five years of age, has remained stagnant since 2005. The lack of improvement in the nutritional status of East Java leads us to examine its nutritional vulnerability as a complement of its nutritional status indicator.

(Insert Figure 2.2)

Spatially, Java has been known for being a province with a high prevalence of undernutrition. 
Among others, the research results of Martianto (1999) in West Java and East Nusa Tenggara showed that the proportion of insecure households (energy intake $<7 \%$ of sufficiency) varied between $49.3 \%$ and $55.3 \%$ in West Java and between $10.4 \%$ and $36 \%$ in East Nusa Tenggara. In addition, they showed that the better was the agro-ecology of a region, the lower was the proportion of households facing food insecurity in that region. Martianto and Ariani (2001) analyzed the data of the National Socio-Economic Survey (Susenas) of 1996 and 1999 and revealed an increased prevalence of malnourishment in the population (energy intake $<7 \%$ of sufficiency) from $14.4 \%$ (28.3 million) in 1996 to $23 \%$ (47.8 million) in 1999. About 30.7 million malnourished people were scattered in the provinces of Java in the same year. This increased prevalence is considered to be the impact of the 1997/1998 economic crisis. The economic crisis also led to an increase in number of poor people from 22.5 million (11.3\%) in 1996 to 37.5 million (18.29\%) in 1999.

Undernutrition in East Java is not new; it has been studied since the 1970s. Kusin, Kardjati, and Sudibia (1979) conducted a survey in nine rural areas and interviewed more than 3,000 mothers of children aged 0-15 years. The study aimed to examine the nutritional status of women in rural areas and found that $18-24 \%$ of the non-pregnant non-lactating, $13-35 \%$ of the lactating, and $33-57 \%$ of the pregnant mothers fell below the nutritional standard. These results varied across the surplus, marginal, and minus areas of their category. Other results by Rahmawati (2016) in the district and city of Malang, East Java showed that there were $21 \%$ cases of stunting in children. Further, Soekarjo et al. (2004) evaluated the effectiveness of weekly vitamin A and iron supplementation in 24 junior high schools in East Java among children aged 12-14 years. The study was conducted to examine the prevalence of low vitamin A and iron intake in school-aged children. Moreover, Amelia (2012) revealed that undernutrition among children in East Java was due to the insufficient ratio of the number of health workers to the number of children under five and the average age at first marriage, which was under 16 years. Finally, Mahmudiono et al. (2016) found that one of the factors causing stunting in children in East Java was low dietary diversity in a household's consumption pattern, which was dominated by rice and other food sources of energy (i.e., oil and fat). 
Related to the aforementioned studies, there have been many studies focusing on nutrition in Indonesia, especially in East Java. However, to the best of our knowledge, the concept of vulnerability has previously not been applied to undernutrition. As opposed to ex post undernutrition analysis, we used the data from East Java, which is a representative region, to empirically analyze the vulnerability to undernutrition. The rest of this paper is organized as follows. Section 2.3 presents some studies on how to measure vulnerability, particularly to undernutrition. Then, we introduce the data and present the estimation methodology in section 2.4. Section 2.5 provides the results, discussion, and policy implications. The final section is the conclusion.

\subsection{Analytical Framework}

The present status of individual nourishment is inadequate to ensure that individuals will continue to uphold their recent condition in the near future given the risks that might switch them over to the other side. Accordingly, the concept of vulnerability has become popular to predict this uncertainty. Furthermore, there are substantial studies on measuring vulnerability in different areas, namely poverty, climate change, natural disaster, food security, and many more. Capaldo et al. (2010) classify them into two broad categories. First, vulnerability is analyzed based on stochastic events. Second, it is analyzed based on the outcome of those events (Bogale, 2012; Chaudhuri et al., 2002; Christiaensen and Boisvert, 2000), which is better suited for policy makers to draw inferences.

More specific to undernutrition vulnerability, Nakelse and Ouedraogo (2010) employed a stereotype logistic regression model to analyze the food vulnerability of Burkina Faso's population in 2006. They found that farm size and diversification activities are the main factors explaining food vulnerability of a household. Furthermore, Scaramozzino (2006) adopted the risk management value-at-risk method to quantify a household's vulnerability to food insecurity. However, this model requires much household data, which are rarely available in developing countries.

Moreover, literature on vulnerability to undernutrition conceptualizes the definition of vulnerability by drawing on vulnerability to poverty. Following Chaudhuri et al. (2002), we defined vulnerability as follows: 


$$
V_{h t}=P\left(c_{h, t+1} \leq Z\right) .
$$

where $V_{h t}$ is the probability that a household's expected nutritional consumption $\left(c_{h, t+1}\right)$ will fall below a threshold (Z).

We used the framework developed by Løvendal and Knowles (2005), which had been used by Capaldo et al. (2010) to help explain the factors determining a household's expected intake of calories, protein, and other micronutrients (Figure 2.3).

(Insert Figure 2.3)

This conceptual framework explains that a household's expected future nutritional status depends largely on the household's present conditions and its ability to adapt to shocks that may occur. A household's present characteristics are observable to policy makers to determine the current nutritional status. On the other hand, a household's future conditions are unknown; these depend on how good households are at managing risks. Consequently, conscientious determination in selecting current household characteristics is crucial.

There have been a number of studies related to current household characteristics to determine a household's future nutrition intake. Most of the researchers use income, household size, and education level as variables to predict future household nutritional status (Biederlack and Rivers, 2009; Capaldo et al., 2010; Nakelse and Ouedraogo, 2010; Scaramozzino, 2006). Research by the World Food Program found that the poor were more vulnerable to nutrition deficiency than were the rich. It is more likely that a poorer household suffers from undernutrition either moderately or severely (Bhattacharya et al., 2004) than a richer one. Thus, income becomes an important variable to predict future nutritional status. Meanwhile, Block et al. (2012) showed that there is a relationship between poverty and undernutrition with different magnitudes of income elasticity. They emphasized that the magnitudes, in terms of income elasticity of poverty and undernutrition, were higher in lowerincome countries than in higher-income developed countries. This is reasonable considering the differing pattern of income spending between the poor and the rich (Huang and Gale, 
2009; Tian and Yu, 2013; Zhou and Yu, 2014). In addition to income, this study employed many other variables to predict a future household's nutritional status, that is, calorie consumption, level of education, gender of household head, employment status, and many more (details are included in section 2.4).

\subsection{Data and Methodology}

The data used in this study are from the national socioeconomic survey (SUSENAS) conducted by Statistics Indonesia (Biro Pusat Statistik/BPS) in 2013. This is a multipurpose household survey, designed and conducted by BPS to gather information in the areas of population, health, education, family planning, and housing, as well as consumption and expenditure. Further, we used two modules from this survey, that is, the CORE (principle) and consumption modules, which are conducted on a quarterly basis each year.

A three-stage stratified sample design was applied considering time and expense and operational feasibility, and accuracy. From each of these strata, a pre-assigned number of villages in East Java Province were selected with probability proportional to the population in the villages. Given the list of villages in the districts in the 2010 census records, a pre-assigned number of kelurahan (an administrative block) were then selected systematically. Sample households from each of the strata formed were selected. Thus, the total sample comprised 29,960 households spread over 38 districts in the province.

Regarding missing data and outliers, we dropped any observation that had too many missing data. Moreover, food consumption records often comprise many measurement errors. Hence, in terms of outliers, we dropped any extreme values that did not fall within threetimes the standard deviation from the mean. As a result, the sample size shrank to around $66 \%$ of the original.

In this study, we focused on the measurement of vulnerability to undernutrition. We followed Chaudhuri et al. (2002) to use cross sectional data considering accessibility and availability, particularly in East Java, Indonesia. Consequently, a stringent assumption was needed regarding the stochastic process involved in generating nutrient consumption. First, we agreed that the dietary nutrient consumption depends on the household's characteristics and 
district specifics, which were observable:

$$
c_{h}=f\left(X_{h} ; \beta\right)+\varepsilon_{i}
$$

where $c_{h}$ is the household's nutrient consumption, $X_{h}$ represents a household's observable characteristics, $\beta$ is a vector of parameters that is the same across households, and $\varepsilon_{i}$ is the idiosyncratic error.

Following Just and Pope (1979), to separate the risk factors from the mean determinant variables, the nutrient consumption function was non-linearly specified as follows:

$$
c_{h}=e^{X_{h} \beta}+\sqrt{X \theta} \varepsilon_{h}
$$

where $\sqrt{X \theta}$ is a risk function and $\varepsilon_{h}$ follows a standard normal distribution, such that

$$
\operatorname{Var}\left(c_{h}\right)=X \theta
$$

Thus, we separated the effect of $X$ (given household's characteristics) on the mean of the output (in this case $c_{h}$ : household consumption) and the effect of $X$ on the variance of $c_{h}$.

Further, we conducted the estimation using the three-step feasible generalized least squares (FGLS) approach. First, we ran a nonlinear least squares (NLS) model based on equation 3 and obtained the estimate $\hat{\beta}$ to explain a household's nutritional consumption. From this step, we also obtained the residuals. However, these predicted residuals were heteroscedastic. Hence, to overcome this issue, our second step was to assess their dependence on the same independent variables through a set of parameters $\theta$. We estimated the following equation by an Ordinary Least Squares (OLS) regression.

$$
\ln \left(\varepsilon_{h}^{*}\right)=X_{h} \theta+u_{h}
$$

where $u_{h}$ is the residual of the second estimation. From this step, we obtained $\hat{\theta}$ and the predicted residuals $\widehat{u_{h}}$. Next, we obtained the variance of each household by squaring the predicted residuals $\widehat{\sigma_{h}^{2}}=X_{h} \hat{\theta}$ in order to get rid of the heteroscedasticity in the first step and take into account $\widehat{\sigma_{h}^{2}}$. 
Our final step was to run a weighted NLS regression for equation (3) with a weight $\sqrt{X_{h} \hat{\theta}}$, which was obtained by calculate the $c_{h}{ }^{*}$ whereby $c_{h}{ }^{*}=c_{h} / \sqrt{X_{h} \hat{\theta}}$. We regress the $c_{h} *$ on $e^{X_{h} \beta-0.5 X_{h} \widehat{\theta}}$

A more efficient $\hat{\beta}$ could be estimated from this step.

Using the estimates of $\hat{\beta}$ and $\hat{\theta}$, we then calculated a household's expected nutrient consumption as follows:

$$
\hat{E}\left(c_{h} \mid X_{h}\right)=X_{h} \hat{\beta}
$$

Further, to calculate a household's vulnerability to undernutrition, we assumed that $\widehat{c_{h}}$ follows a normal distribution such that each household's estimated probability would be given by

$$
\widehat{V_{h}}=P\left(c_{h}<z \mid X_{h}\right)=\Phi\left(\frac{z-e^{X_{h} \widehat{\beta}}}{\sqrt{X_{h} \widehat{\theta}}}\right)
$$

where $\widehat{V_{h}}$ reflects the probability that a household would become undernourished in the near future, with an extreme value of 0 representing an invulnerable household and 1 representing a very vulnerable household. In addition, $z$ is the threshold (provided in the next section) and $\Phi($.$) denotes the cumulative density of a standard normal distribution.$

Furthermore, since the value of $\widehat{V_{h}}$ could lie between the two extreme values mentioned above $(0,1)$, we needed to determine which households should be categorized as more or less likely to be undernourished. We followed the work of Capaldo et al. (2010) and Chaudhuri et al. (2002) to consider 0.5 as the cutoff point; a value less than or equal to 0.5 is considered stable or invulnerable, and values above 0.5 have the opposite interpretation (vulnerable). Complementing the analysis, we also used 0.9 as a cutoff point to analyze households with extremely vulnerable conditions.

Accordingly, $z$ is the threshold by which we examined the probability that a household would be considered undernourished in the future. We used the threshold issued by The Ministry of 
Health Republic of Indonesia, which has been adjusted typically for Indonesians (see Table 2.7 in the appendix). We then utilized the information on household characteristics to predict their food intake in the near future. In calculating the daily food intake per person, we utilized the information from the survey covering the consumption intake of every household using a 7-day recall method. From this information, we converted the food intake into the food compositions that we wished to evaluate.

After estimating the level of vulnerability to undernourishment of every household, we continued our analysis to assess the co-movements of the vulnerability index with household characteristics, specifically to identify types of vulnerable households in accordance with their socioeconomic characteristics and district-specific information.

\subsection{Results and Discussion}

\subsubsection{Sample Descriptive Statistics}

We estimated daily per-capita energy, protein, and other micronutrient consumption as functions of several variables representing a household's demographic and social characteristics, infrastructure access, social security instruments, and asset holdings. Table 2.2 lists all variables with their corresponding mean values and standard deviations.

(Insert Table 2.2\}

Table 2.2 provides information about the average calories, protein, calcium, and iron intake per person in East Java, Indonesia. Subsequently, household-specific socioeconomic and district-specific variables are presented. Surprisingly, only intake of iron was above that of the dietary reference intake (DRI). On average, calories, protein, and calcium consumption were below the DRI issued by the Indonesian Ministry of Health in the period under study.

For more details, information on a household's structure includes the age of the household's head, the highest level of education attained (as a proxy of human capital investment), female-headed households, and the number of labor in the household. The latter also shows labor availability within the household to describe multiple income sources. A household's assets are measured through the cemented floor area. The number of cell phones reveals the 
openness of households to information, for instance, from the internet or social media. Further, we used motorcycle ownership to describe wealth as well as the potential mobility of the households to acquire food. Per-capita income was used to show earning capacity. We used ex-post data on an idiosyncratic shock (illness) and the number of insurances and government and non-governmental programs from which a household received assistance to calculate the approximate coping capacity given a sudden shock. In this application, we could not complement the data on household characteristics with information on covariate shocks due to data unavailability.

Finally, we also utilized a set of variables that reflect the district infrastructure in which the household was located as well as the rural or urban areas dominated by agricultural activities to provide a better depiction of the situation surrounding the households. The provision of public facilities represented the household's accessibility to infrastructure, which included the number of primary schools, clinics (medical facilities including integrated service stations and hospitals), and markets.

\subsubsection{Regression results}

This study aims at examining the household minimum dietary macronutrient (energy and protein) and micronutrient (calcium and iron) requirements under light physical activity using the Just and Pope model (just and Pope, 1979). Related to the model, there are at least two reasons that we consider important to the analysis. First, the non-least square regressions of the Just and Pope model separate the effects of covariates' movements and covariates' variance to the output, thereby yielding a more accurate result. Second, the Just and Pope model follows the steps of an FGLS, which acknowledges the problem of heteroscedasticity and endogeneity. Thus, the results are more reliable. This research was not an attempt to identify direct causes of nutrition deficiency, but merely to examine the different types of household characteristics that are predicted to fall in the category of an undernourished household. However, the results presented here are to be considered preliminary. The estimation results for calories and protein consumption and their variance are reported in Table 2.3a while the results for the other micronutrients are presented in Table 2.3b.

(Insert Table 2.3a) 
Variables related to household demographics (size of the household, and household head's age) behaved similarly for most energy, protein, and nutrients under observation. The number of family members significantly reduced the amount of energy, protein, and nutrients consumed in a household. These results are in line with Capaldo et al. (2010) possibly because the household's income to buy food remained relatively unchanged, while the increase in the number of family members would result in smaller proportions of food consumed by each family member. Further, age of the household head had no significant effect on calorie and protein consumption, but had a positive impact on other micronutrient intake, specifically calcium and iron.

Educational background of the household head, which reflects the human capital aspect, had different results on calorie and protein intake compared to micronutrients. For the latter, the highest year of education of the household head significantly increased iron and calcium consumption. In contrast, the opposite was true of calorie and protein intake. This indicates that educational background plays an important role in deciding what food the household should consume. As such, the finding supports Cox et al. (1998), D'Avanzo et al. (1997), and Valliant et al. (2012) in terms of the effect of education in promoting the consumption of micronutrients.

Moreover, asset ownership (the size of the cement floor in the household and motorcycle ownership), which reflects asset coping capacity and wealth related variables, behaved as expected for all macro- and micronutrients in the study. The cemented floor area was positively related to the increase in food consumption whereas households that did not own a motorcycle tended to consume less energy, proteins, and micronutrients. Being a sign of wealth, it is possible that motorcycle ownership also reflects transportation access, thereby enabling the household to obtain food with more varied choices and convenience. In addition, the number of cell phones, potentially used to describe the speed of information transfer, was found to behave differently from expectations. The number of cell phones contributed to lower levels of macro- and micronutrient consumptions. However, an increase in the number of cell phones was associated with a lower variance in food consumption. A possible 
explanation is that a cell phone cannot be used without incurring additional costs, which ultimately reduces the income to buy food. Unfortunately, we were unable to differentiate the degree of mobile phone usage based on the individual's purpose. Hence, we were only able to capture its general impact on household consumption.

Furthermore, other variables reflecting household coping capacity, namely number of labor in the household, number of insurance possessed, assistance programs from government and non-government entities, engagement with any financial institutions, and income, mostly contributed to increased household food consumption. The only exception was the variable engagement with a financial institution, which had a slightly negative though non-significant effect on energy, protein, calcium, and iron consumption. Moreover, we observed that shock occurrence in the household, which we proxied as illness, had a positive insignificant effect on increasing household food consumption, possibly because this variable cannot provide rich information, for example, the intensity of the illness and its length and severity, and thereby potentially lowers the income earned. Regarding the last variable in the household characteristics group, that is, whether it is a female-headed household, we found that the micronutrient consumption increased significantly when the household head was female. On the contrary, this variable did not have a significant effect on energy and protein consumption.

Turning to district-specific variables, we found the number of primary schools to be negatively correlated with food consumption. This result is puzzling as government nutrient intervention was conducted commonly through primary schools to meet the needs of the targeted students as well as to run the program, for example, by distributing fortified supplementary biscuits and vitamins via these schools. As such, we had expected the opposite result from this variable. Moreover, variables showing the impact of better provision in terms of number of health facilities, expressed as number of clinics, total number of integrated service stations, and number of hospitals, were expected to contribute little (insignificant) towards increasing the intake of dietary energy and protein. However, this variable showed a significant correlation in increasing the intake of micronutrients, which means that the greater the number of health facilities provided by the government, the greater the increase in food consumption, especially micronutrient consumption. Further, villagers were found to 
consume less food than people living in cities, based on the results of this study. This can be attributed to the higher purchasing power of people in urban areas than of those in rural areas. In addition, the availability of a range of food is more varied in a city than in a village. Furthermore, people living in an area where agricultural products have a bigger share in the Gross Regional Domestic Product (GRDP) tend to consume more calories, protein, as well as micronutrients than the ones living in non-agricultural areas.

Based on the results explained above, there are two micronutrient-related variables, which act differently in terms of the consumption of calcium and iron. Education and the number of health facilities negatively affect the consumption of energy and proteins while being positively correlated to the intake of calcium and iron.

After the regression process, we estimated the prediction of food consumption by calculating equation 5. From this, we got the predicted value of nutrient consumption.

(Insert Figure 2.4)

Figure 2.4 describes the distribution of nutrient consumption per day in relation to its prediction. We draw a reference line showing the threshold of minimum consumption of calories recommended by the Ministry of Health of Indonesia ${ }^{2}$. From figure 2.4, we classified the samples into four quadrants. In the first quadrant (upper right), the household consumption and prediction are equal to or exceed the threshold. This could be considered the optimum condition, where samples are stable. The second quadrant (upper left) is one in which the household consumption is equal to or exceeds the threshold; however, in the near future, they are predicted to consume lesser than the threshold level. We consider this condition as leading to undernourished vulnerability. Further, the third quadrant (lower left) is one in which both the real and predicted values are below the threshold. Households in this category are trapped in a condition where they do not have enough resources to improve their future consumption. Finally, the fourth quadrant (lower right) is one in which

\footnotetext{
$2,150 \mathrm{kcal}$ of calories, $60 \mathrm{~g}$ of proteins, $1000 \mathrm{mg}$ of calcium, and $13 \mathrm{mg}$ of iron per person per day.
} 
households consume lesser than the threshold level, but are predicted to have a minimum threshold nutrient consumption in the near future.

(Insert tables 2.4a, 2.4b, 2.4c, and 2.4d)

Tables 2.4a, b, c, and d present the descriptive statistics of household characteristics by quadrant categories, to enable us to compare the characteristics of each quadrant. Apparently, only per-capita income and cement floor show a significant difference compared to other characteristics across quadrants. Looking at quadrants 1 and 2, where household calorie consumption is above the threshold, we find that households in the nourished and stable condition (food secure) have double the per-capita income of households in quadrant 2 on and average, and a larger cement floor. Other characteristics that have a smaller effect on higher prediction results are household size, education, and access to finance. Households in quadrant 1 have a smaller household size, are more educated, and have greater access to finance compared to their counterparts in quadrant 2.

Turning to households in quadrants 3 and 4 where the current calorie consumption is under the threshold, the patterns are the same as presented above. Households in quadrant 3 are predicted to have a future calorie consumption that is lower than the threshold (food insecure); they have a per-capita income that is half that of households in quadrant 4 on average. Furthermore, a smaller cement floor area is attributed to households in quadrant 3 , compared to their counterparts. Household size, education of household head, and access to finance also show similar patterns as presented in quadrants 1 and 2 . Households in quadrant 3 have a larger household size, are less educated, and have less access to finance compared to their counterparts in quadrant 4.

\subsubsection{Vulnerability Analysis}

Following the regression analysis, we present the vulnerability estimates by analyzing the magnitude of household vulnerability in more detail. The first part of this section shows the vulnerability of the households in East Java, Indonesia. We then examine the co-movements of the vulnerability index with the household and district characteristics to identify the 
features of vulnerable households.

Vulnerability indices resulting from equation 6 show the vulnerability of the East Javanese. We point out that around half the sampled population was found to be vulnerable based on our model, except for iron intake ( $22 \%$ of the people were vulnerable). This transient condition applied not only to those whose food consumption was below the threshold, but also to those whose current nutritional status was considered "nourished."

(Insert Table 2.5)

Table 2.5 is a representation of households' undernutrition vulnerability shown by the consumption of calories, protein, calcium, and iron per day in East Java. Overall, it is evident that the vulnerability rate for macro- and micronutrients is fairly high. The largest number of households was prone to be lacking in protein intake, followed by calories, calcium, and iron. Specifically, the rate of vulnerable households reached $59.56 \%, 56.3 \%, 43.34 \%$, and $22.95 \%$ for protein, calorie, calcium, and iron intake, respectively. From these figures, the proportion of vulnerable households emerged in two groups: households whose nutritional status was (a) secure and (b) insecure. Although households that had a secure nutritional status tend to be vulnerable to undernutrition, the number remained large enough to be ignored. Hence, these findings support Capaldo's findings, which explained that there is an overlap between undernourished and vulnerable households. Being undernourished does not necessarily make one vulnerable, and not all nourished households are stable (invulnerable). In line with these findings, it can be clearly seen that there is a dynamic transitory condition faced by households falling in and out of food insecurity that certainly should be addressed by policy makers.

It is imperative that policy makers consider the dimensions of undernutrition from two perspectives: temporal, related to the duration of undernutrition, and the severity of undernourishment of the households. Each of these has its own characteristics and causes, which ought to be differentiated to enable optimal policy formulation.

Chronic and transitory are two terms proposed by Devereux (2006) to explain the time 
dimension of undernutrition; chronic is the long-term condition of being undernourished whereas transitory is an acute condition where households' lack of food is temporary. Often, the triggers of becoming transient regarding lack of food are sequences of droughts, floods, and rapid increase in food prices without sufficient handling, which could deteriorate access to food. Repeated transitory conditions could force households to dispose their assets to be able to buy food until they fall below the minimum asset threshold. This path possibly shifts the transient households to become chronic households.

We enrich the analysis by presenting the co-movement of the vulnerability index, the way vulnerability is associated with other variables, and varies across different households. Table 2.5 tabulates the values of some household characteristics, on average, in seven different classes of vulnerability.

(Insert Table 2.6)

Table 2.6 shows how household characteristics change across the seven classes of vulnerability, two classes under the $50 \%$ threshold, and five above. Some patterns can be observed based on the table. Not surprisingly, the intake of calorie, protein, calcium, and iron showed a decrease with an increase in vulnerability level. Furthermore, demographic characteristics (household size and age) indicated different patterns. The number of household members is negatively associated with the index, while age has a distinct association across macro- and micronutrients. Next, calorie consumption tends to increase with the increase in the vulnerability index. However, it acts in the opposite manner for protein, calcium, and iron intake. These results are rather puzzling. It might be statistically because of the established threshold per age, which differs for calorie consumption and for the other two nutrients across the different age levels. Another reason could be that older people pay more attention to what they eat. In other words, older people tend to choose nutritious food over staple resulting in a richer nutritional intake. Next, regarding the human capital variable (education), we find that a lower level of education of the household head is associated with a higher vulnerability rate. Moreover, variables representing the asset coping capacity (motorcycle ownership and cement floor area) showed a decreasing, though slight, monotonic pattern. Further, a decreasing pattern was also shown by per-capita income 
indicating that the lower the income of the households, the more vulnerable they are to undernutrition. Moreover, households' coping capacity, which we attempt to measure by the number of insurance programs they possessed, access to government and non-government assistance programs, and to financial institutions, showed no obvious pattern across the vulnerability index except for the number of insurance programs, which tends to increase as the vulnerability index increases. Number of cell phones is associated positively with the vulnerability index. This finding is in line with the previous regression results (Tables 2.3a and 2.3b).

Furthermore, district-specific variables, that is, number of primary schools, number of clinics, and number of markets, which show access to public facilities, reveal decreasing trends across the vulnerability index except for the number of primary schools, which shows no clear pattern. From these results, we may infer that the more vulnerable is a household, the lesser are the public facilities available in its district.

Finally, the only idiosyncratic shock variable in this model, illness, exhibited a positive relationship with the indices for all nutrients. These results support the empirical findings of some researchers (Capaldo et al., 2010; Scaramozzino, 2006).

The last group among the seven vulnerability level classifications (table 2.6) shows the 90\% cut off. Specifically, the households under this category have at least a $90 \%$ chance of being undernourished. Regarding their macro and micronutrient intakes, all consumptions are below the standard of consumption reference levels.

Compared to other groups, this group has more family members (more than four), the least economic resources such as income and assets (cement floor area in the household), and more workers within the household, although the data indicates that a majority of them work in labor-intensive farming, characterized by low income. Hence, despite more working members, their contribution to increasing the family income does not significantly increase consumption. In terms of education, this class tends to have a lower educational background, on average, compared to other classes. Since income and education are two crucial determinants in promoting the consumption of macro and micronutrients based on the 
regression results and vulnerability analysis, it is important to consider promoting income and education improvements especially among the $90 \%$ cut-off class.

\subsubsection{Some policy implications}

In this section, we reiterated some of the results that have significant implications for response from the government as a policy maker.

Realizing the existence of nutrition deficiencies is not a recent phenomenon; nutrient deficiencies have been prevalent since the time of the Dutch colonialization in Indonesia, as proven by the rampant beri-beri problem of the late 19th century (Ravallion, 1990). A number of empirical studies have revealed that income could be one of the key points in dealing with the nutrition problem, without neglecting the danger of this type of policy. Income increase could possibly lead to the wrong direction, as we see the emergence of the obesity problem. However, to some point, cash transfer might be the answer for the most vulnerable households, especially in East Java.

Accordingly, representing the results described in the previous section, per-capita income is superior to the other variables, having a positive relationship with food consumption (calorie, protein, calcium, and iron). Additionally, it monotonically decreases with the increase in vulnerability indices for all nutrients considered in this study. These facts show that increasing the income through certain programs could help in eliminating nutritional deprivation.

To date, there are at least two transfer policies implemented by the Indonesian government targeted at the poor, which initially aimed to help people cope with the slowdown of the economy because of the 1998 crisis. These are cash transfers (conditional and unconditional) and in-kind transfers (subsidized rice program, health insurance, Program Keluarga Harapan, etc). The goal of both programs is to increase the real per-capita household income. Berlingieri (2009) found that transfer policies had a significant effect on children's nutritional status in Indonesia, as measured by the decrease in stunting of children and low birth weight. Nonetheless, Afkar and Matz (2015) revealed that there is an overlap between these policies, which should be evaluated by the Indonesian government. Moreover, Ravallion (1990) highlighted the income effect on nutrition in developing countries; he suggested that the 
nutritional status of poorer countries would be more impacted by changes in income. Another study conducted by Skoufias, Tiwari, and Zaman (2011) pointed out that cash transfer programs could play an integral role in helping households protect their consumption of essential nutrients, particularly during crisis periods. In terms of the types of food that households consume in relation to their income, Rae (1999) explains that higher expenditure leads to consumption away from staple foods toward more nutritious foods.

Well-targeted cash transfer programs optimistically could reduce the vulnerability to nutrition deficiency and could improve nutrition levels. Given the aforementioned study finding that there is an overlap among programs, this could possibly be a challenge for the government to ensure the effectiveness and the efficacy of their programs. Well-designed safety net programs with careful implementation and good corporate governance could be crucial to reaching a sustainable nutrition level.

Furthermore, as part of the social safety net program, the Indonesian government provides in-kind transfers in the form of health insurance. There are many types of public health insurance provided by the government of Indonesia including Jamkesmas (community health insurance), Jamkesda (district health insurance), and Jampersal (childbirth insurance). These provide the citizens with social protection and health focusing on basic health care. The main goal is to reduce the burden on the poor so that they do not lose the opportunity to use their resources to spend on other basic needs, including nutrition fulfillment. Unfortunately, we failed to capture the effect of the different insurance programs as mostly, every household had all types of insurance.

The regression results showed a positive relationship between the number of insurance programs owned by a household and the household's intake of nutrients. Complementarily, the vulnerability indices indicate that the more vulnerable are the households, the greater is the number of insurance programs that they possess. There are at least two possible explanations for this. First, it is plausible that the more vulnerable the household, the more health insurance they need to support their lives. We regard this as a sign of well-targeted insurance programs because the vulnerable community has sufficient access to such help. The other explanation would be that health insurance programs have little impact on nutrient 
improvement, considering that the programs have been in force since more than five years before the data used in this study were collected (i.e., 2013). Despite this, the health insurance programs can improve the food security status of the households through increased performance at a minimum cost. Thus, the nutrient absorption could be optimal if a person is healthy. In addition, health insurance needs to include nutrition care facilities in their coverage instead of basic health care alone, since in the long run, a patient with a better nutritional status could significantly reduce a future health care cost compared to one with a lower nutritional status (Lorefält et al., 2011).

Further, the educational background of the household head shows a crucial result in that its impact on macronutrient consumption differs from that on micronutrient consumption. Higher educational background relates to higher micronutrient consumption and lower macronutrient consumption. Culturally, Indonesians eat rice more than any other food items in their three meals a day. An increase in education levels appears to have a positive impact in shifting the consumption pattern to a more nutritious intake. The Indonesian perspective on a balance diet is reflected in the food pyramid that has long been implemented. This pyramid-shaped graph shows which foods are considered important and which are to be eaten sparingly to achieve a healthy diet. In this pyramid, rice accounts for the largest share of food, and vegetables and protein sources account for lesser proportions. This leads to some policy recommendations to evaluate the long-standing concept of the food pyramid.

Another micronutrient-related variable is the number of health facilities in the area where the household is based. This exhibited a negative effect on the consumption of energy and protein, whereas it was positively correlated to the intake of calcium and iron as the number of health insurance increases. If the government considers sufficient nutrition to be significant for the health of the society, it would be worthwhile to establish nutrition counseling in every clinic, especially in those located in rural areas. The innovation of nutrition-based insurance, which is separate from health insurance, potentially provides an opportunity for researchers to shed light on its impact on other aspects, particularly on economic development. As a tool, it also makes it easier for the government to focus more on policy evaluation in understanding the potential solution to the problem of nutrition vulnerability. 


\subsection{Conclusion and Future Research Recommendations}

The undernutrition vulnerability analysis revealed that half the sample was vulnerable to undernutrition. Among the macro- and micronutrients examined in this study, a majority of households lacked protein intake, followed by calories, calcium, and iron. The current nutritional status cannot be used to determine whether a household is at risk of being undernourished in the future. In other words, vulnerability was observed not only among those whose nutritional status was food insecure, but also among food secure households. Among the secure households, $15 \%$ of the people were vulnerable to under-consumption of calories, $13 \%$ to protein, $12 \%$ to calcium, and $6 \%$ to iron, which could not have been determined by considering their current nutritional status only.

Concerning the co-movement of the vulnerability indices associated with variables, per-capita income showed the most obvious pattern across vulnerability indices. Increasing income could be the key to deal with nutrition problems. This would call for the promotion of cash transfer policies that are well targeted and well designed. Moreover, two micronutrientrelated variables are educational background and the health facilities provided in the region. Higher educational background and a greater number of health facilities are related to higher micronutrient consumption and lower macronutrient intake. The household head's educational background plays an important role though its effect differs on the consumption of macro- versus micronutrients. A higher (lower) education level promotes (hampers) the consumption of micronutrients. The household head's education is also a factor that decreases vulnerability to nutrition deficiency with a higher education level being related to better micronutrient intake by the household. Variables related to asset coping capacity, namely, cement floor area in a household and motorcycle ownership, contributed positively in combating undernutrition. Moreover, insurance, which are a form of in-kind transfer, were found to have the potential to help vulnerable households by supporting in the provision of basic health. The remaining household characteristics exhibited weaker patterns.

Finally, we acknowledge that the results that we have presented are to be considered preliminary. This study employed cross-sectional socioeconomic survey data of households in East Java Province (Indonesia), which provides information on their consumption and expenditure using a one-week recall period approach. From this, we obtained the aggregate 
consumption data for each household. Hence, our regression and vulnerability results are not considered statuses of individual nutrition. Owing to data limitations, we only captured the mean nutritional status and estimated the risk of suffering from nutrition deficiencies compared to the mean value. Further, we could not capture the distribution of food among household members, which could lead to other important findings related to the dual burden of malnutrition in the region. In addition, we also failed to capture food consumed away from home, which potentially may lead to other important findings. In addition, education, as an important household characteristic, fails to reflect household knowledge of nutrition, specifically. Furthermore, the only government assistance program that has a direct goal of nutrition improvement is Program Keluarga Harapan. Unfortunately, we could not use the data from this program because of too many missing values in the survey data. Thus, improving data quality is important for further research. These limitations provide room for improvement in future research. 


\subsection{Appendix of Chapter two}

Tables and Figures

Table 2.1. East Java Province's Socio and Economic Performances

\begin{tabular}{lrrrrr}
\hline \multicolumn{1}{c}{ Indicators } & \multicolumn{5}{c}{ Year } \\
\cline { 2 - 6 } & 2012 & 2013 & 2014 & 2015 & 2016 \\
\hline Growth rate (\%) & 6.6 & 6.1 & 5.9 & 5.4 & 5.5 \\
Share of GRDP to national economy (\%) & 6 & 6.07 & 5.86 & 5.44 & 5.55 \\
Population (\% to National population) & 15.42 & 15.32 & 15.21 & 15.11 & 15.10 \\
Poverty rate (\%) & 13.24 & 12.64 & 12.35 & 12.31 & 11.95 \\
\hline
\end{tabular}

Source: BPS (2017) 
Table 2.2: Summary of Variables

\begin{tabular}{|c|c|c|c|}
\hline Variable & Unit & Mean & $\begin{array}{l}\text { Standard } \\
\text { Deviation }\end{array}$ \\
\hline \multicolumn{4}{|l|}{ Dependent Variables } \\
\hline Calorie intake & kilocalories & 1934.89 & 432.29 \\
\hline Protein intake & grams & 52.39 & 14.098 \\
\hline Calcium intake & Milligrams & 887.84 & 298.59 \\
\hline Iron intake & Milligrams & 14.297 & 5.184 \\
\hline \multicolumn{4}{|l|}{ Household specific Variables } \\
\hline Household size & Units & 3.53 & 1.37 \\
\hline Age of household head & Years & 50.85 & 13.08 \\
\hline $\begin{array}{l}\text { Household head's number of years of } \\
\text { education }\end{array}$ & Years & 6.59 & 4.06 \\
\hline Female headed household ${ }^{1}$ & Proportion & 0.16 & 0.37 \\
\hline Number of labors in the household & Persons & 1.85 & 0.94 \\
\hline Number of insurance programs & Units & 0.44 & 0.56 \\
\hline Number of assistance programs & Units & 0.18 & 0.46 \\
\hline Per capita income & Rupiahs & 478244.9 & 250554.3 \\
\hline Number of occurrences of illness (shock) & Units & 0.54 & 0.93 \\
\hline Engagement with financial institution ${ }^{2}$ & Proportion & 0.08 & 0.27 \\
\hline Motorcycle ownership ${ }^{3}$ & Proportion & 0.71 & 0.45 \\
\hline Number of cell phones & Units & 1.47 & 1.08 \\
\hline Cement floor area in house & Square meters & 77.96 & 48.39 \\
\hline \multicolumn{4}{|l|}{ District specific Variables } \\
\hline Number of primary schools & Units & 8.29 & 22.03 \\
\hline Number of clinics & Units & 296.36 & 645.01 \\
\hline Number of markets & Units & 52.36 & 132.71 \\
\hline Rural versus urban area ${ }^{4}$ & Proportion & 0.49 & 0.49 \\
\hline Share of agricultural sector in GRDP ${ }^{5}$ & Proportion & 0.76 & 0.43 \\
\hline $\begin{array}{l}\text { Female }=1 ; \text { male }=0 \\
\text { Yes }=1 ; \text { no }=0 \\
\text { Yes }=1 ; \text { no }=0 \\
\text { Rural }=1 ; \text { urban }=0 \\
\text { Yes }=1 ; \text { no }=0\end{array}$ & & & \\
\hline
\end{tabular}


Table 2.3a: Regression results for calorie and protein consumption

\begin{tabular}{|c|c|c|c|c|c|c|c|c|}
\hline & \multicolumn{2}{|c|}{$\begin{array}{l}\text { Per capita }(p c) \text { calorie } \\
\text { (cal) consumption } \\
\text { (cons) }\end{array}$} & \multicolumn{2}{|c|}{ Variance of cal cons } & \multicolumn{2}{|c|}{$\begin{array}{l}\text { Pc protein } \\
\text { consumption }\end{array}$} & \multicolumn{2}{|c|}{$\begin{array}{l}\text { Variance of protein } \\
\text { cons }\end{array}$} \\
\hline & Coef & Std Error & Coef & Std Error & Coef & Std Error & Coef & Std Error \\
\hline \multicolumn{9}{|l|}{$\begin{array}{l}\text { Household } \quad \text { specific } \\
\text { Variables }\end{array}$} \\
\hline Household size & $-0.0131 * * *$ & 0.0015 & $-0.0304 * * *$ & 0.0086 & $-0.0277^{* * *}$ & 0.0018 & $-0.0267^{* * *}$ & 0.0086 \\
\hline Age of household head & -0.0520 & 0.0058 & $-0.1543^{* * *}$ & 0.0348 & -0.0003 & 0.0070 & -0.0068 & 0.0349 \\
\hline $\begin{array}{l}\text { Education of household } \\
\text { head }\end{array}$ & $-0.0060 * * *$ & 0.0005 & $-0.0071 * * *$ & 0.0029 & $-0.0057 * * *$ & 0.0006 & $-0.0089 * * *$ & 0.0029 \\
\hline \multirow{2}{*}{$\begin{array}{l}\text { Female headed household } \\
\text { No. of labors in the } \\
\text { household }\end{array}$} & 0.0030 & 0.0039 & 0.0080 & 0.0235 & -0.0009 & 0.0047 & 0.0104 & 0.0236 \\
\hline & $0.0031 *$ & 0.0017 & $0.0172 *$ & 0.0101 & $0.0117 * * *$ & 0.0021 & 0.0122 & 0.0101 \\
\hline \multirow{2}{*}{$\begin{array}{l}\text { No. of insurance programs } \\
\text { No. of assistance } \\
\text { programs }\end{array}$} & $0.0108^{* * *}$ & 0.0024 & $-0.0395^{* * *}$ & 0.0145 & $0.0074 * *$ & 0.0029 & -0.0212 & 0.0145 \\
\hline & $0.0126^{* * *}$ & 0.0034 & 0.0184 & 0.0201 & 0.0028 & 0.0041 & 0.0024 & 0.0202 \\
\hline \multirow{2}{*}{$\begin{array}{l}\text { Per capita income } \\
\text { No. of occurrences of } \\
\text { illness (shock) }\end{array}$} & $0.3197^{* * *}$ & 0.0040 & $0.2483^{* * *}$ & 0.0241 & $0.4166^{* * *}$ & 0.0048 & $0.4659 * * *$ & 0.0242 \\
\hline & 0.0062 & 0.0014 & 0.0129 & 0.0086 & 0.0018 & 0.0017 & -0.0009 & 0.0086 \\
\hline $\begin{array}{l}\text { Financial institution } \\
\text { engagement }\end{array}$ & -0.0028 & 0.0057 & 0.0059 & 0.0343 & -0.0046 & 0.0068 & -0.0397 & 0.0344 \\
\hline Motorcycle ownership & $0.0089 * *$ & 0.0036 & $-0.0428^{* * *}$ & 0.0211 & $0.0456 * * *$ & 0.0043 & $-0.1067^{* * *}$ & 0.0212 \\
\hline \multirow{2}{*}{$\begin{array}{l}\text { No. of cell phones } \\
\text { Cement floor area in } \\
\text { house }\end{array}$} & $-0.0322^{* * *}$ & 0.0018 & $-0.0297^{* * *}$ & 0.0106 & $-0.0232^{* * *}$ & 0.0021 & $-0.0344 * * *$ & 0.0106 \\
\hline & 0.0028 & 0.0027 & -0.0112 & 0.0161 & $0.0137^{* * *}$ & 0.0032 & $-0.0426^{* * *}$ & 0.0161 \\
\hline \multicolumn{9}{|l|}{ District specific Variables } \\
\hline $\begin{array}{l}\text { Number of primary } \\
\text { schools }\end{array}$ & $-0.1718^{* * *}$ & 0.0418 & 0.0013 & 0.0018 & $-0.0466 * * *$ & 0.0077 & 0.0002 & 0.0018 \\
\hline Number of clinics & 0.0004 & 0.0004 & 0.0023 & 0.005 & $0.0009 *$ & 0.0001 & 0.00037 & 0.0086 \\
\hline Number of markets & $0.0152 *$ & 0.0058 & 0.0012 & 0.0003 & 0.0004 & 0.0011 & $-0.0006^{* * *}$ & 0.0003 \\
\hline Rural versus urban area & $-0.5115^{* * *}$ & 0.4209 & $-0.0359 * *$ & 0.0180 & $-0.4948^{* * *}$ & 0.0771 & $-0.0304 *$ & 0.0181 \\
\hline $\begin{array}{l}\text { Share of agricultural } \\
\text { sector in GRDP }\end{array}$ & $8.2745^{* * *}$ & 0.5484 & 0.0118 & 0.0239 & $1.2982^{* * *}$ & 0.0974 & $0.0853^{* * *}$ & 0.0239 \\
\hline Constant & $3.7041^{* * *}$ & 0.0574 & $2.8004 * * *$ & 0.3379 & $-1.2558^{* * *}$ & 0.0687 & $-3.8754 * * *$ & 0.3388 \\
\hline R squared & 0.9688 & & 0.013 & & 0.9564 & & 0.0326 & \\
\hline No. of observations & 19,952 & & 19,952 & & 19,952 & & 19,952 & \\
\hline
\end{tabular}

Note: All variables that are not expressed as proportions are in log form. 
Table 2.3b: Regression results for calcium and iron consumption

\begin{tabular}{|c|c|c|c|c|c|c|c|c|}
\hline & \multicolumn{2}{|c|}{$\begin{array}{l}\text { Pc calcium } \\
\text { consumption }\end{array}$} & \multicolumn{2}{|c|}{$\begin{array}{l}\text { Variance of calcium } \\
\text { consumption }\end{array}$} & \multicolumn{2}{|c|}{ Pc iron consumption } & \multicolumn{2}{|c|}{$\begin{array}{l}\text { Variance of iron } \\
\text { consumption }\end{array}$} \\
\hline & Coef & Std Error & Coef & Std Error & Coef & Std Error & Coef & Std Error \\
\hline \multicolumn{9}{|l|}{$\begin{array}{l}\text { Household } \\
\text { Variables }\end{array}$} \\
\hline Household size & $-0.0256^{* * *}$ & 0.0024 & $-0.0842^{* * *}$ & 0.0088 & $-0.1970 * * *$ & 0.0034 & $-0.1650 * * *$ & 0.0091 \\
\hline Age of household head & $0.0605^{* * *}$ & 0.0097 & -0.0083 & 0.0354 & $0.0998^{* * *}$ & 0.0122 & $0.0054 * * *$ & 0.0007 \\
\hline $\begin{array}{l}\text { Education of household } \\
\text { head }\end{array}$ & $0.0088^{* * *}$ & 0.0008 & $-0.0050 *$ & 0.0030 & $0.0020 *$ & 0.0010 & $0.0072^{* *}$ & 0.0031 \\
\hline $\begin{array}{ll}\text { Female } & \text { headed } \\
\text { household } & \end{array}$ & $-0.0082 *$ & 0.0066 & $0.0418^{* * *}$ & 0.0239 & $0.0332 * * *$ & 0.0081 & $0.0501 * *$ & 0.0254 \\
\hline $\begin{array}{l}\text { No. of labors in the } \\
\text { household }\end{array}$ & $0.0167^{* * *}$ & 0.0028 & -0.0078 & 0.0102 & $0.0142 *$ & 0.0074 & 0.0157 & 0.0107 \\
\hline $\begin{array}{l}\text { No. of insurance } \\
\text { programs }\end{array}$ & $0.0226 * * *$ & 0.0039 & $-0.0374 * *$ & 0.0147 & 0.0077 & 0.0051 & -0.0058 & 0.0151 \\
\hline $\begin{array}{l}\text { No. of assistance } \\
\text { programs }\end{array}$ & $0.0208^{* * *}$ & 0.0055 & -0.0227 & 0.0205 & 0.0039 & 0.0078 & $0.0576^{* * *}$ & 0.0215 \\
\hline Per capita income & $0.4134 * * *$ & 0.0066 & $0.2967 * * *$ & 0.0241 & $0.1726^{* * *}$ & 0.0086 & $0.0542^{* *}$ & 0.0262 \\
\hline $\begin{array}{l}\text { No. of occurrences of } \\
\text { illness (shock) }\end{array}$ & 0.0103 & 0.0023 & -0.0099 & 0.0087 & 0.0059 & 0.0029 & -0.0140 & 0.0091 \\
\hline $\begin{array}{ll}\text { Financial institution } \\
\text { engagement }\end{array}$ & $-0.0273^{* * *}$ & 0.0093 & -0.0301 & 0.0349 & 0.0091 & 0.0125 & -0.0554 & 0.0364 \\
\hline Motorcycle ownership & $0.0409 * * *$ & 0.0060 & $-0.0680^{* * *}$ & 0.0215 & $0.0315^{* * *}$ & 0.0074 & $-0.0935^{* * *}$ & 0.0223 \\
\hline No. of cell phones & $-0.0325^{* * *}$ & 0.0030 & $-0.0248^{* *}$ & 0.0107 & $0.0174 * *$ & 0.0084 & $0.0256^{* *}$ & 0.0111 \\
\hline $\begin{array}{l}\text { Cement floor area in } \\
\text { house }\end{array}$ & $0.0215^{* * *}$ & 0.0044 & -0.0217 & 0.0163 & 0.0077 & 0.0057 & $-0.0565^{* * *}$ & 0.0173 \\
\hline \multicolumn{9}{|l|}{ District specific Variables } \\
\hline No. of primary schools & $-0.2447 * * *$ & 0.0363 & -0.0005 & 0.0018 & $-0.0023^{* * *}$ & 0.0003 & $0.0006 * * *$ & 0.0001 \\
\hline No. of clinics & $0.0008^{* *}$ & 0.0004 & 0.0000 & 0.0000 & $0.0010^{* * *}$ & 0.0001 & $-0.0001^{* * *}$ & 0.0000 \\
\hline No. of markets & $0.0096 *$ & 0.0050 & 0.0002 & 0.0003 & $0.0145^{* * *}$ & 0.0009 & $-0.0009 * * *$ & 0.0003 \\
\hline Rural versus urban area & $-0.984 * * *$ & 0.3704 & 0.0118 & 0.0184 & 0.2503 & 0.0542 & 0.2860 & 0.0193 \\
\hline $\begin{array}{l}\text { Share of agricultural } \\
\text { sector in GRDP }\end{array}$ & $7.8424 * * *$ & 0.4656 & -0.0175 & 0.0242 & 0.1145 & 0.0927 & $-0.0413^{* * *}$ & 0.0300 \\
\hline Constant & $1.1251^{* * *}$ & 0.0941 & $1.5684 * * *$ & 0.3379 & -0.0023 & 0.0003 & 0.0006 & 0.0001 \\
\hline R squared & 0.9233 & & 0.0348 & & 0.861 & & 0.06 & \\
\hline No. of observations & 19,952 & & 19,952 & & 19,952 & & 19,952 & \\
\hline
\end{tabular}

Note: All variables that are not expressed as proportions are in log form. 
Table 2.4a: Descriptive statistics of household characteristics based on their four quadrant categories in terms of calorie consumptions

\begin{tabular}{lrr|rr}
\hline & \multicolumn{4}{c}{ Quadrant } \\
\cline { 2 - 5 } & \multicolumn{1}{c}{1} & 2 & 3 & \multicolumn{1}{c}{4} \\
\hline Household size & 2.82 & 3.81 & 4.1 & 3.06 \\
Age of household head & 50.43 & 50.47 & 51.44 & 50.41 \\
Highest education of household head & 7.44 & 6.51 & 6.37 & 6.86 \\
Female headed household & 0.23 & 0.13 & 0.14 & 0.17 \\
No. of labors in the household & 1.61 & 1.81 & 2.34 & 2.03 \\
No. of insurance programs & 0.40 & 0.45 & 0.48 & 0.47 \\
No. of assistance programs & 0.18 & 0.17 & 0.17 & 0.18 \\
Per capita income & 680002.6 & 384386.9 & 335161.7 & 565591.1 \\
No. of occurrences of illness (shock) & 0.64 & 0.58 & 0.47 & 0.41 \\
Financial institution engagement & 0.09 & 0.08 & 0.06 & 0.08 \\
Motorcycle ownership & 0.71 & 0.72 & 0.69 & 0.70 \\
No. of cell phones & 1.36 & 1.52 & 1.54 & 1.39 \\
Cement floor area in house & 82.01 & 77.04 & 74.43 & 80.65 \\
No. of primary schools & 564 & 553 & 548 & 575 \\
No. of clinics & 1444 & 1361 & 1349 & 1427 \\
No. of markets & 76 & 77 & 75 & 78 \\
Rural versus urban area & 0.47 & 0.49 & 0.50 & 0.44 \\
Share of agricultural sector in GRDP & 0.78 & 0.75 & 0.74 & 0.79 \\
\hline
\end{tabular}


Table 2.4b: Descriptive statistics of household characteristics based on their four quadrant categories in terms of protein consumptions

\begin{tabular}{lrr|rr}
\hline & \multicolumn{4}{c}{ Quadrant } \\
\cline { 2 - 5 } & \multicolumn{1}{c}{1} & 2 & 3 & \multicolumn{1}{c}{4} \\
\hline Household size & 2.48 & 3.30 & 3.87 & 2.69 \\
Age of household head & 52.82 & 50.50 & 50.44 & 52.10 \\
Highest education of household head & 7.46 & 6.38 & 6.40 & 6.83 \\
Female headed household & 0.26 & 0.16 & 0.13 & 0.24 \\
Number of labors in the household & 1.54 & 1.82 & 1.94 & 1.63 \\
Number of insurance programs & 0.37 & 0.43 & 0.46 & 0.40 \\
Number of assistance programs & 0.15 & 0.17 & 0.18 & 0.17 \\
Per capita income & 85906.50 & 472501.90 & 381245.80 & 742075.80 \\
Number of occurrences of illness (shock) & 0.55 & 0.56 & 0.51 & 0.59 \\
Financial institution engagement & 0.09 & 0.07 & 0.07 & 0.10 \\
Motorcycle ownership & 0.67 & 0.71 & 0.72 & 0.70 \\
Number of cell phones & 1.42 & 1.41 & 1.50 & 1.39 \\
Cement floor area in house & 85.77 & 76.70 & 76.31 & 82.57 \\
Number of primary schools & 528.33 & 551.84 & 569.88 & 565.24 \\
Number of clinics & 1361.2 & 1353.78 & 1399.33 & 1348.47 \\
Number of markets & 83 & 65 & 45 & 72 \\
Rural versus urban area & 0.46 & 0.52 & 0.52 & 0.44 \\
Share of agricultural sector in GRDP & 0.64 & 0.52 & 0.49 & 0.50 \\
\hline
\end{tabular}


Table 2.4c: Descriptive statistics of household characteristics based on their four quadrant categories in terms of calcium consumptions

\begin{tabular}{lrr|rr}
\hline & \multicolumn{4}{c}{ Quadrant } \\
\cline { 2 - 5 } & \multicolumn{1}{c}{1} & 2 & 3 & \multicolumn{1}{c}{4} \\
\hline Household size & 2.21 & 3.39 & 4.00 & 2.43 \\
Age of household head & 55.08 & 50.14 & 49.70 & 54.17 \\
Highest education of household head & 6.64 & 6.62 & 6.61 & 6.85 \\
Female headed household & 0.3 & 0.14 & 0.12 & 0.27 \\
Number of labors in the household & 1.43 & 1.82 & 1.99 & 1.54 \\
Number of insurance programs & 0.41 & 0.43 & 0.45 & 0.38 \\
Number of assistance programs & 0.14 & 0.17 & 0.19 & 0.15 \\
Per capita income & 790704.40 & 460721.10 & 396125.80 & 777379.00 \\
Number of occurrences of illness (shock) & 0.69 & 0.52 & 0.50 & 0.62 \\
Financial institution engagement & 0.07 & 0.07 & 0.08 & 0.09 \\
Motorcycle ownership & 0.70 & 0.71 & 0.75 & 0.66 \\
Number of cell phones & 1.13 & 1.46 & 1.60 & 1.27 \\
Cement floor area in house & 81.23 & 77.06 & 77.90 & 82.68 \\
Number of primary schools & 561 & 579 & 591 & 623 \\
Number of clinics & 1399 & 1402 & 1381 & 1365 \\
Number of markets & 78.61 & 51.16 & 47.45 & 49.87 \\
Rural versus urban area & 0.5 & 0.51 & 0.6 & 0.52 \\
Share of agricultural sector in GRDP & 0.71 & 0.77 & 0.76 & 0.71 \\
\hline
\end{tabular}


Table 2.4d: Descriptive statistics of household characteristics based on their four quadrant categories in terms of iron intake

\begin{tabular}{lrr|rr}
\hline & \multicolumn{4}{c}{ Quadrant } \\
\cline { 2 - 5 } & \multicolumn{1}{c}{1} & \multicolumn{2}{c}{3} & \multicolumn{1}{c}{4} \\
\hline Household size & 2.93 & 5.40 & 5.49 & 3.66 \\
Age of household head & 51.09 & 50.63 & 50.41 & 48.69 \\
Highest education of household head & 10 & 6.5 & 4.9 & 9 \\
Female headed household & 0.12 & 0.07 & 0.06 & 0.14 \\
Number of labors in the household & 1.71 & 0.27 & 1.03 & 1.03 \\
Number of insurance programs & 0.43 & 0.46 & 0.46 & 0.43 \\
Number of assistance programs & 0.3 & 0.24 & 0.1 & 0.23 \\
Per capita income & 505350.4 & 361708.6 & 326028.7 & 446889.6 \\
Number of occurrences of illness (shock) & 0.35 & 0.43 & 0.56 & 0.41 \\
Financial institution engagement & 0.075 & 0.069 & 0.03 & 0.045 \\
Motorcycle ownership & 0.86 & 0.67 & 0.33 & 0.74 \\
Number of cell phones & 2.04 & 1.31 & 1.81 & 1.55 \\
Cement floor area in house & 83.78 & 76.72 & 50.48 & 75.6 \\
Number of primary schools & 556.9 & 585.6 & 617.2 & 564.7 \\
Number of clinics & 1443.6 & 1468.1 & 1477.4 & 1422.4 \\
Number of markets & 83.53 & 82.65 & 74.83 & 76.83 \\
Rural versus urban area & 0.5 & 0.54 & 0.6 & 0.54 \\
Share of agricultural sector in GRDP & 0.88 & 0.79 & 0.65 & 0.78 \\
\hline
\end{tabular}


Table 2.5. Current status of food security and vulnerability prediction

\begin{tabular}{|c|c|c|c|}
\hline Current status & $\begin{array}{c}\text { Vulnerable } \\
\text { (\%) }\end{array}$ & Invulnerable (\%) & $\begin{array}{c}\text { Total } \\
\text { Percentage }\end{array}$ \\
\hline \multicolumn{4}{|l|}{ Calorie } \\
\hline Food secure & 15.01 & 30.6 & 45.61 \\
\hline Food insecure & 41.29 & 13.1 & 54.39 \\
\hline Total & 56.3 & 43.7 & 100 \\
\hline \multicolumn{4}{|l|}{ Protein } \\
\hline Food secure & 13.61 & 27.79 & 41.4 \\
\hline Food insecure & 45.95 & 12.65 & 58.6 \\
\hline Total & 59.56 & 40.44 & 100 \\
\hline \multicolumn{4}{|l|}{ Calcium } \\
\hline Food secure & 12.55 & 37.18 & 49.73 \\
\hline Food insecure & 30.79 & 19.49 & 50.28 \\
\hline Total & 43.34 & 56.67 & 100.01 \\
\hline \multicolumn{4}{|l|}{ Iron } \\
\hline Food secure & 6.25 & 49.51 & 55.76 \\
\hline Food insecure & 16.7 & 27.54 & 44.24 \\
\hline Total & 22.95 & 77.05 & 100 \\
\hline
\end{tabular}


Table 2.6. Levels of vulnerability to food insecurity - relationships with selected variables

\begin{tabular}{|c|c|c|c|c|c|c|c|c|}
\hline & & \multicolumn{7}{|c|}{ Vulnerability Index } \\
\hline & & $0-20$ & 20.1-50 & $50.1-60$ & $60.1-70$ & 70.1-80 & $80.1-90$ & $90.1-100$ \\
\hline Per-capita & calorie & 2261.55 & 2105.07 & 1955.09 & 1823.59 & 1710.05 & 1660.93 & 1651.91 \\
\hline \multirow[t]{3}{*}{ consumption } & protein & 69.78 & 64.71 & 61.60 & 57.05 & 52.51 & 48.95 & 45.26 \\
\hline & calcium & 1158.60 & 1089.19 & 1017.40 & 888.40 & 822.50 & 792.96 & 764.22 \\
\hline & iron & 17.12 & 12.69 & 12.74 & 12.14 & 10.95 & 9.95 & 8.96 \\
\hline \multirow{4}{*}{$\begin{array}{l}\text { Household } \\
\text { size }\end{array}$} & calorie & 2.73 & 3.02 & 3.46 & 3.73 & 4.00 & 4.16 & 4.44 \\
\hline & protein & 2.47 & 2.60 & 2.96 & 3.22 & 3.44 & 3.62 & 4.09 \\
\hline & calcium & 2.09 & 2.38 & 2.86 & 3.33 & 3.67 & 3.96 & 4.37 \\
\hline & iron & 2.95 & 3.88 & 5.23 & 5.54 & 5.72 & 6.00 & 5.23 \\
\hline \multirow{4}{*}{$\begin{array}{l}\text { Age of } \\
\text { household } \\
\text { head }\end{array}$} & calorie & 50.51 & 50.40 & 50.34 & 50.71 & 51.10 & 51.28 & 51.82 \\
\hline & protein & 52.01 & 52.89 & 51.62 & 51.24 & 50.88 & 50.20 & 50.09 \\
\hline & calcium & 55.59 & 54.40 & 52.11 & 50.26 & 49.64 & 49.42 & 49.09 \\
\hline & iron & 50.88 & 47.97 & 50.53 & 49.83 & 49.75 & 49.08 & 49.53 \\
\hline \multirow{4}{*}{$\begin{array}{l}\text { Highest } \\
\text { education of } \\
\text { household } \\
\text { head }\end{array}$} & calorie & 7.27 & 6.52 & 6.46 & 6.31 & 6.33 & 6.34 & 6.29 \\
\hline & protein & 8.09 & 6.72 & 6.48 & 6.44 & 6.40 & 6.31 & 6.40 \\
\hline & calcium & 7.04 & 6.61 & 6.35 & 6.58 & 6.52 & 6.77 & 6.69 \\
\hline & iron & 6.55 & 6.96 & 6.28 & 6.29 & 5.88 & 6.00 & 5.47 \\
\hline \multirow{4}{*}{$\begin{array}{l}\text { Number of } \\
\text { labors in } \\
\text { household }\end{array}$} & calorie & 1.61 & 1.71 & 1.82 & 1.92 & 2.00 & 2.04 & 2.10 \\
\hline & protein & 1.55 & 1.59 & 1.73 & 1.79 & 1.84 & 1.87 & 1.99 \\
\hline & calcium & 1.41 & 1.50 & 1.71 & 1.78 & 1.87 & 1.94 & 2.10 \\
\hline & iron & 1.66 & 1.90 & 2.25 & 2.38 & 2.54 & 2.59 & 2.68 \\
\hline \multirow{4}{*}{$\begin{array}{l}\text { Female } \\
\text { headed } \\
\text { household }\end{array}$} & calorie & 0.21 & 0.18 & 0.15 & 0.14 & 0.13 & 0.13 & 0.13 \\
\hline & protein & 0.26 & 0.25 & 0.18 & 0.16 & 0.17 & 0.14 & 0.12 \\
\hline & calcium & 0.33 & 0.27 & 0.18 & 0.14 & 0.12 & 0.14 & 0.10 \\
\hline & iron & 0.15 & 0.11 & 0.08 & 0.06 & 0.08 & 0.07 & 0.07 \\
\hline \multirow{4}{*}{$\begin{array}{l}\text { Number of } \\
\text { insurance } \\
\text { programs }\end{array}$} & calorie & 0.40 & 0.41 & 0.43 & 0.45 & 0.49 & 0.46 & 0.48 \\
\hline & protein & 0.35 & 0.40 & 0.42 & 0.43 & 0.41 & 0.45 & 0.47 \\
\hline & calcium & 0.39 & 0.40 & 0.41 & 0.43 & 0.43 & 0.46 & 0.47 \\
\hline & iron & 0.43 & 0.44 & 0.44 & 0.48 & 0.49 & 0.44 & 0.47 \\
\hline \multirow{4}{*}{$\begin{array}{l}\text { Number of } \\
\text { assistance } \\
\text { programs }\end{array}$} & calorie & 0.19 & 0.17 & 0.17 & 0.16 & 0.19 & 0.18 & 0.17 \\
\hline & protein & 0.17 & 0.15 & 0.15 & 0.16 & 0.17 & 0.17 & 0.19 \\
\hline & calcium & 0.13 & 0.15 & 0.14 & 0.16 & 0.17 & 0.19 & 0.20 \\
\hline & iron & 0.15 & 0.20 & 0.21 & 0.24 & 0.25 & 0.19 & 0.22 \\
\hline \multirow{4}{*}{$\begin{array}{l}\text { Per capita } \\
\text { income }\end{array}$} & calorie & 772744.30 & 549302.50 & 420152.20 & 373791.20 & 343963.40 & 324630.20 & 307310.10 \\
\hline & protein & 980958.70 & 718709.30 & 558926.80 & 488988.70 & 440223.30 & 400812.20 & 346525.90 \\
\hline & calcium & 932964.30 & 732468.10 & 531995.00 & 461326.10 & 412355.70 & 397027.30 & 359884.40 \\
\hline & iron & 719425 & 633591.50 & 557643.90 & 341779.30 & 345092.70 & 314339.80 & 320779.10 \\
\hline \multirow{4}{*}{$\begin{array}{l}\text { Number of } \\
\text { occurrences } \\
\text { of illness } \\
\text { (shock) }\end{array}$} & calorie & 0.64 & 0.58 & 0.53 & 0.53 & 0.47 & 0.45 & 0.48 \\
\hline & protein & 0.66 & 0.61 & 0.57 & 0.55 & 0.53 & 0.56 & 0.50 \\
\hline & calcium & 0.75 & 0.63 & 0.57 & 0.51 & 0.54 & 0.49 & 0.48 \\
\hline & iron & 0.57 & 0.50 & 0.46 & 0.48 & 0.44 & 0.41 & 0.47 \\
\hline \multirow{4}{*}{$\begin{array}{l}\text { Engagement } \\
\text { with } \\
\text { financial } \\
\text { institution }\end{array}$} & calorie & 0.09 & 0.08 & 0.07 & 0.07 & 0.07 & 0.07 & 0.07 \\
\hline & protein & 0.10 & 0.09 & 0.07 & 0.07 & 0.08 & 0.07 & 0.07 \\
\hline & calcium & 0.08 & 0.08 & 0.07 & 0.07 & 0.07 & 0.09 & 0.08 \\
\hline & iron & 0.07 & 0.08 & 0.08 & 0.08 & 0.10 & 0.09 & 0.06 \\
\hline Motorcycle & calorie & 0.74 & 0.72 & 0.71 & 0.70 & 0.70 & 0.70 & 0.70 \\
\hline \multirow{2}{*}{ ownership } & protein & 0.73 & 0.72 & 0.72 & 0.7 & 0.69 & 0.67 & 0.67 \\
\hline & calcium & 0.77 & 0.72 & 0.76 & 0.72 & 0.61 & 0.63 & 0.66 \\
\hline
\end{tabular}




\begin{tabular}{|c|c|c|c|c|c|c|c|c|}
\hline & & \multicolumn{7}{|c|}{ Vulnerability Index } \\
\hline & & $0-20$ & $20.1-50$ & $50.1-60$ & 60.1-70 & $70.1-80$ & $80.1-90$ & $90.1-100$ \\
\hline & iron & 0.81 & 0.81 & 0.79 & 0.82 & 0.67 & 0.78 & 0.8 \\
\hline \multirow{4}{*}{$\begin{array}{l}\text { Number of } \\
\text { cell phones }\end{array}$} & calorie & 1.41 & 1.34 & 1.41 & 1.48 & 1.51 & 1.55 & 1.67 \\
\hline & protein & 1.52 & 1.34 & 1.38 & 1.42 & 1.46 & 1.43 & 1.53 \\
\hline & calcium & 1.18 & 1.19 & 1.31 & 1.43 & 1.49 & 1.64 & 1.69 \\
\hline & iron & 1.29 & 1.65 & 1.80 & 1.85 & 2.00 & 1.93 & 1.90 \\
\hline \multirow{4}{*}{$\begin{array}{l}\text { Cement } \\
\text { floor area in } \\
\text { house }\end{array}$} & calorie & 86.16 & 78.22 & 76.42 & 74.12 & 74.23 & 78.02 & 74.18 \\
\hline & protein & 89.70 & 81.55 & 79.73 & 77.71 & 76.42 & 74.82 & 75.93 \\
\hline & calcium & 82.50 & 81.56 & 76.61 & 77.34 & 75.81 & 78.25 & 78.60 \\
\hline & iron & 88.89 & 85.19 & 83.08 & 79.66 & 79.16 & 75.94 & 75.57 \\
\hline \multirow{4}{*}{$\begin{array}{l}\text { Number of } \\
\text { primary } \\
\text { schools }\end{array}$} & calorie & 562 & 571 & 565 & 561 & 551 & 551 & 541 \\
\hline & protein & 567 & 569 & 573 & 568 & 556 & 554 & 544 \\
\hline & calcium & 559 & 562 & 564 & 553 & 551 & 547 & 541 \\
\hline & iron & 568.17 & 564.93 & 603.30 & 590.20 & 598.85 & 618.71 & 634.18 \\
\hline \multirow{4}{*}{$\begin{array}{l}\text { Number of } \\
\text { clinics }\end{array}$} & calorie & 1454 & 1430 & 1412 & 1388 & 1361 & 1375 & 1325 \\
\hline & protein & 1386.726 & 1403.234 & 1416.9250 & 1402.7190 & 1386.162 & 1373.954 & 1356.177 \\
\hline & calcium & 445.36 & 351.77 & 300.83 & 278.42 & 292.33 & 296.59 & 271.72 \\
\hline & iron & 1464.8 & 1434.89 & 1494.18 & 1467.54 & 1466.33 & 1487.33 & 1501.23 \\
\hline \multirow{4}{*}{$\begin{array}{l}\text { Number of } \\
\text { markets }\end{array}$} & calorie & 75 & 76 & 78 & 78 & 76 & 77 & 75 \\
\hline & protein & 85.55 & 75.05 & 64.03 & 59.20 & 50.44 & 48.01 & 45.47 \\
\hline & calcium & 79.83 & 76.65 & 55.07 & 46.62 & 49.22 & 50.94 & 45.64 \\
\hline & iron & 76.50 & 76.59 & 83.91 & 83.96 & 84.00 & 89.69 & 96.08 \\
\hline \multirow{4}{*}{$\begin{array}{l}\text { Rural versus } \\
\text { urban area }\end{array}$} & calorie & 0.49 & 0.45 & 0.47 & 0.47 & 0.51 & 0.51 & 0.53 \\
\hline & protein & 0.48 & 0.49 & 0.49 & 0.47 & 0.45 & 0.45 & 0.47 \\
\hline & calcium & 0.60 & 0.55 & 0.47 & 0.47 & 0.46 & 0.50 & 0.48 \\
\hline & iron & 0.48 & 0.49 & 0.48 & 0.44 & 0.38 & 0.43 & 0.37 \\
\hline \multirow{4}{*}{$\begin{array}{l}\text { Share of } \\
\text { agricultural } \\
\text { sector }\end{array}$} & calorie & 0.76 & 0.79 & 0.79 & 0.76 & 0.75 & 0.74 & 0.72 \\
\hline & protein & 0.66 & 0.73 & 0.75 & 0.77 & 0.77 & 0.79 & 0.78 \\
\hline & calcium & 0.67 & 0.72 & 0.76 & 0.77 & 0.79 & 0.74 & 0.77 \\
\hline & iron & 0.79 & 0.78 & 0.83 & 0.82 & 0.83 & 0.86 & 0.91 \\
\hline
\end{tabular}


Table 2.7. Dietary Requirements Information, 2013

\begin{tabular}{lcccc}
\hline \multicolumn{1}{c}{ Age (years) } & Energy (Kcal) & Protein (g) & Calcium $(\mathbf{m g})$ & Iron $(\mathbf{m g})$ \\
\hline Male & & & & \\
$19-29$ & 2,725 & 62 & 1100 & 13 \\
$30-49$ & 2,625 & 65 & 1000 & 13 \\
$50-64$ & 2,325 & 65 & 1000 & 13 \\
$65-80$ & 1,900 & 62 & 1000 & 13 \\
$>80$ & 1,525 & 62 & 1000 & 13 \\
Female & & & & \\
$19-29$ & 2,250 & 56 & 1100 & 26 \\
$30-49$ & 2,150 & 57 & 1000 & 26 \\
$50-64$ & 1,900 & 57 & 1000 & 12 \\
$65-80$ & 1,550 & 56 & 1000 & 12 \\
$>80$ & 1,425 & 55 & 1000 & 12 \\
\hline
\end{tabular}

Source: Ministry of Health Republic of Indonesia 
Figure 2.1. Comparison between National and East Java Growth Rates (percentage)

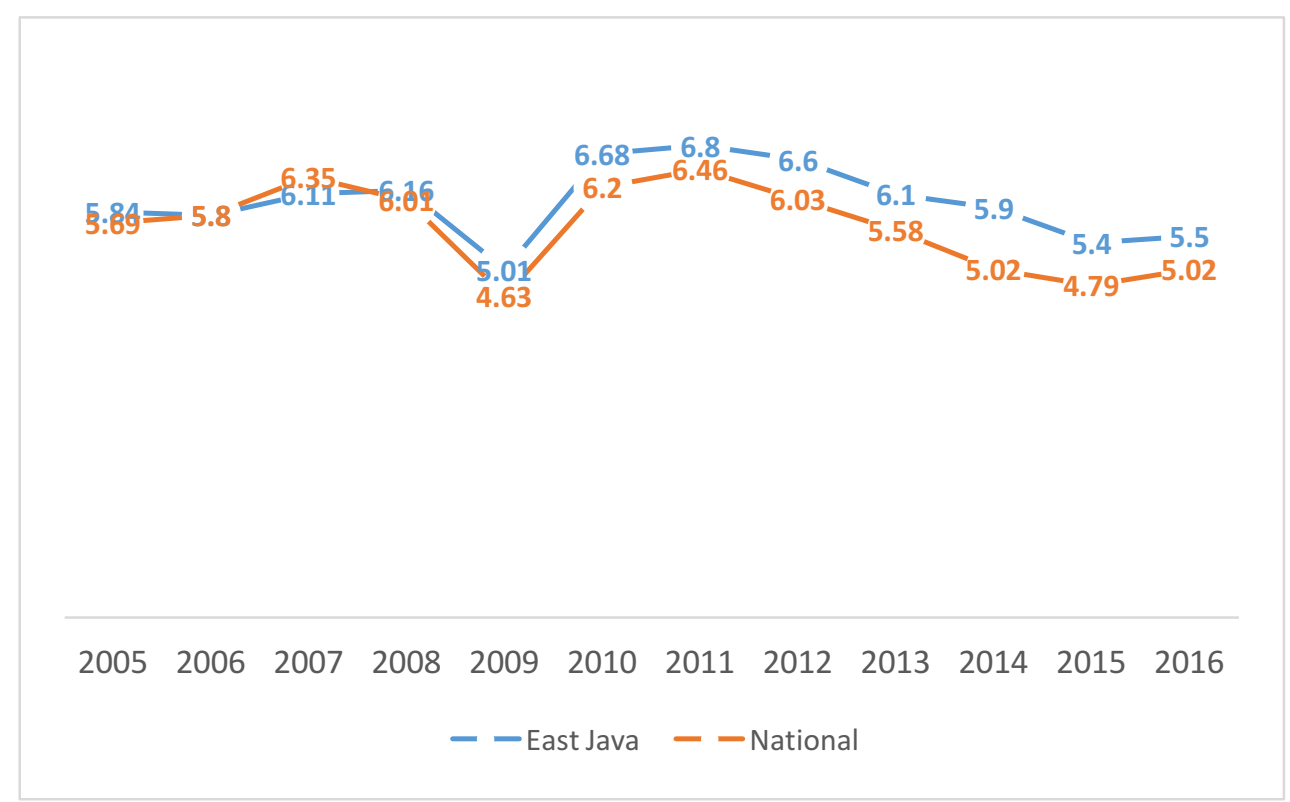

Source: BPS $\underline{(2017)}$

Figure 2.2. Comparison between National and East Java Poverty Rates (percentage)

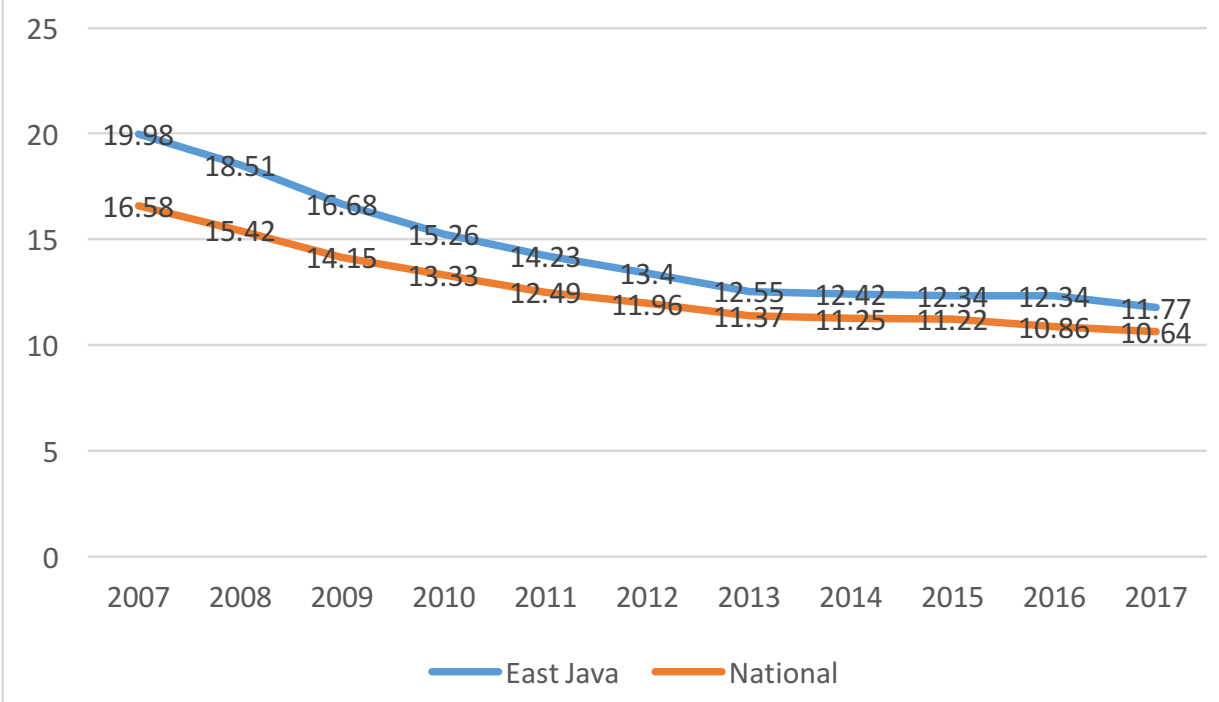

Source: BPS 
Figure 2.3. Conceptual Framework of Vulnerability to Future Food Insecurity

$\begin{array}{ccc}\text { Present food } & \text { Events } t_{0} t_{1} & \text { Expected future food } \\ \text { security status } t_{0} & \text { Status } t_{0} & \text { security status } t_{1}\end{array}$

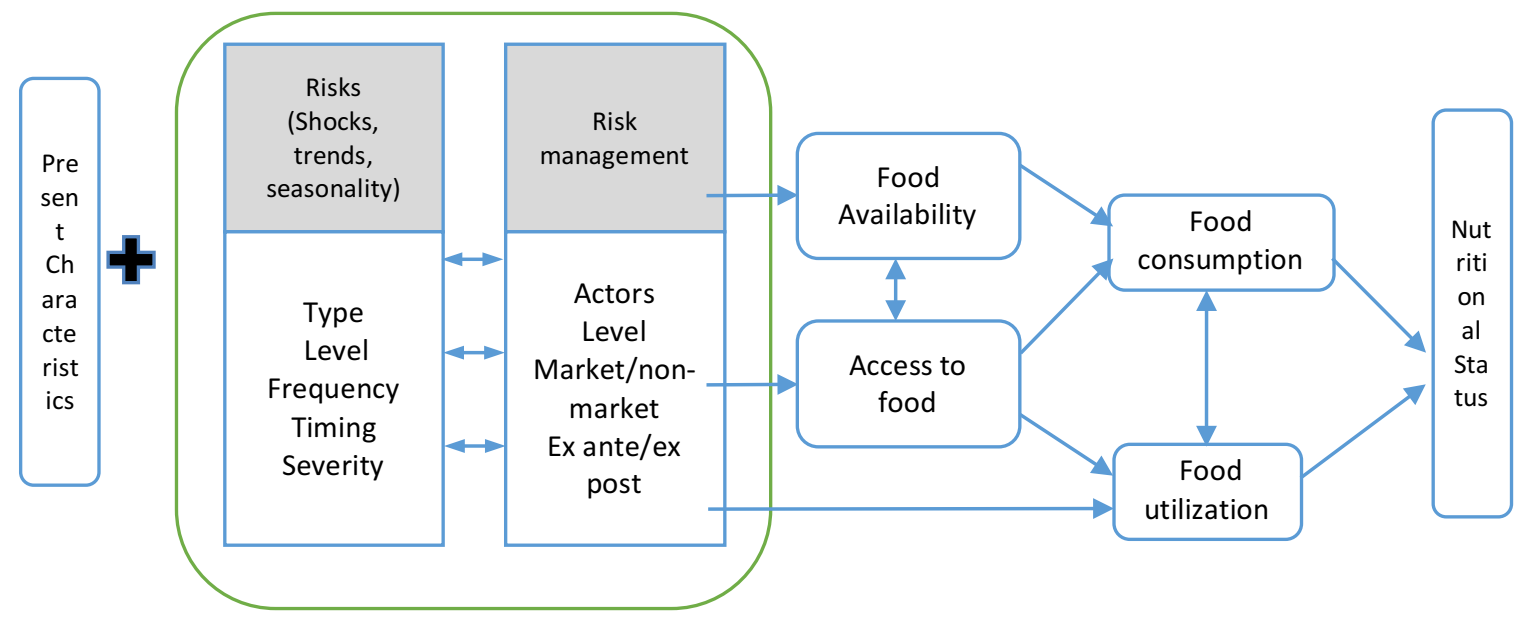

Source: Løvendal and Knowles (2005) 
Figure 2.4: Distributions of average daily nutrient consumptions and its prediction values

b.Calorie

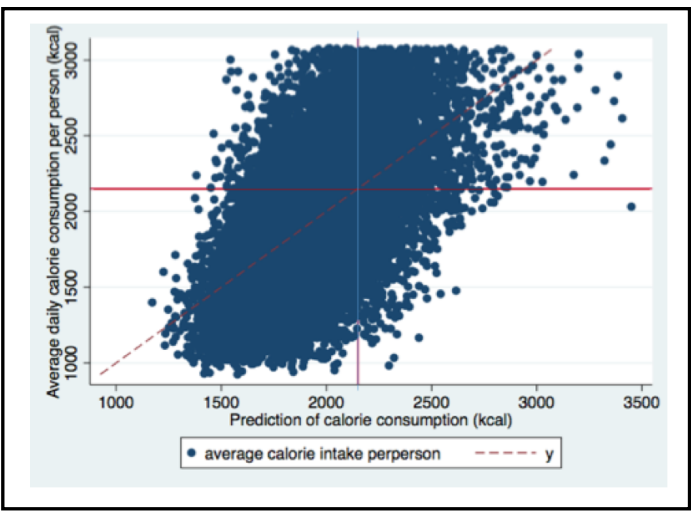

c. Calcium

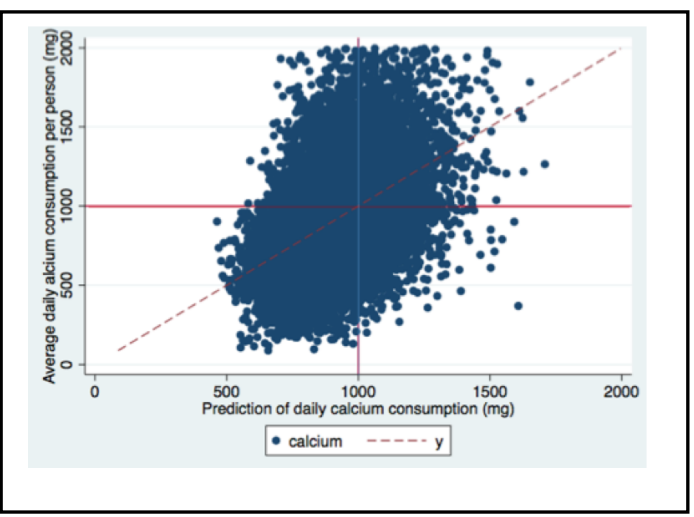

a. Protein

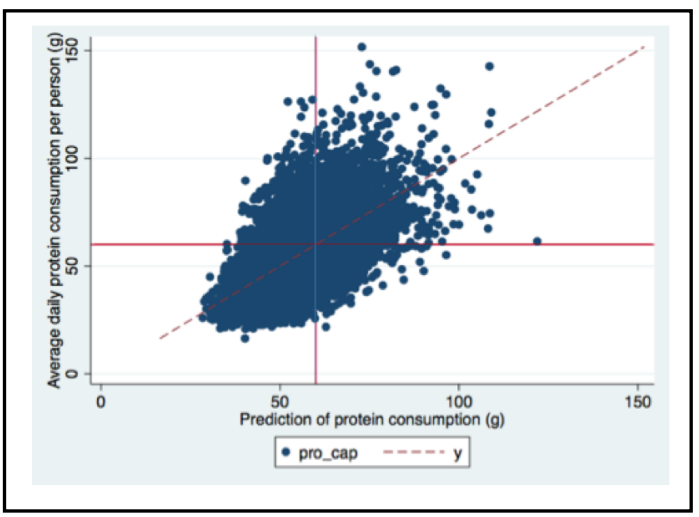

d. Iron

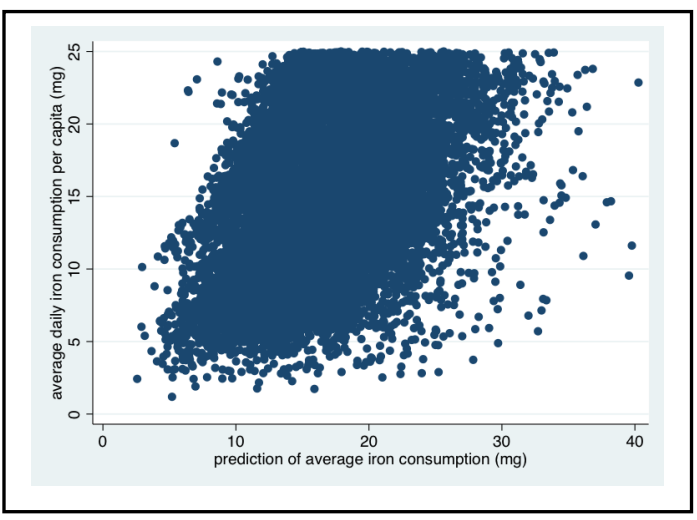




\title{
CHAPTER THREE
}

\section{MARKET INTEGRATION BETWEEN THE INDONESIAN RICE MARKET AND THE WORLD}

\begin{abstract}
This study aims to examine the price transmission behavior of the international markets, represented by Thailand and Vietnam, toward the domestic Indonesian market. We use a vector error correction model (VECM) and threshold vector error correction model (TVECM) to observe symmetric and asymmetric as well as threshold effects of the short-run adjustment process. The results suggest that there are asymmetric behaviors for both sets of paired countries (Indonesia-Thailand and Indonesia-Vietnam) as shown by significant differences in adjustments in the case of squeezed and stretched margins. For the threshold model, only Indonesia-Thailand's error correction term showed a different speed of adjustment when the deviation from the long-run equilibrium exceeded the threshold value of $9.3 \%$. In conclusion, both symmetric and asymmetric models confirmed that the domestic market is co-integrated with the international markets, although the price transmission between the two is weak.
\end{abstract}




\subsection{Introduction}

The dynamics of food modernization cannot replace the vital role of rice in the lives of the people of Indonesia. For centuries, rice has been the main source of calories in the form of staple as well as processed rice-based food. For an average diet, the intake of calories from staples is nearly 50\% (Widarjono and Rucbha, 2016) and the per-capita consumption is the highest among the ASEAN rice-importing countries. According to the Ministry of Agriculture, the Indonesian per-capita consumption of rice was 114 kg/year in 2015 (BPS, 2017), while Philippines and Malaysia consumed $112.67 \mathrm{~kg} /$ year and $82.3 \mathrm{~kg} /$ year, respectively (USDA, 2017). In addition, the rice sector is prominent for labor in rural area. More than $50 \%$ of their income is from growing rice as well as providing services and trading in this sector (BPS, 2014). Thus, concerning all these interests, the price of rice is by itself crucial.

To date, recent developments in the domination of rice as a strategic commodity in Indonesia coupled with the increased trading activities among nations re-emphasize how integrated the Indonesian rice market is with the world market. Given that domestic rice production cannot fulfill domestic demand, import policy has become an option to fulfill the need for rice as well as to control its price. Accordingly, the movement of price in the international market, to some extent, is transmitted to the Indonesian rice price. Spatial market integration analysis provides the ability to examine price movements in a market in relation to price changes in other markets. Hence, the dynamics in one market could be the signal for the movements in other markets (McNew, 1996).

Relying on import policy for many years creates a dependency on the world market as the suppliers. To achieve price stabilization in the domestic economy, the government has an instituted an import policy since the 1990s with several breaks (import bans) in 2004 and 2008. Bilateral trade between Indonesia and Thailand, one of the largest rice exporting countries, has been established. More recently, Indonesia also imports medium rice from

Vietnam. These two countries have become important as medium rice suppliers for Indonesia's domestic food security. 
Further, the integration among markets leads to price formation since examining persistent deviation from equilibrium may result in a better understanding of the risk of price shocks. The ability to gauge the magnitudes of shocks being transmitted from the international to domestic market enables governments to better formulate policies related to domestic rice price stability. Since the price of rice is critical for most Indonesians, particularly the poor, gaining an overall understanding of the rice price formation from an international source of shock is crucial.

Subsequently, there are at least two aspects other than the aforementioned policy aspects that are relevant for Indonesia to be more concerned about the domestic and international rice price relationship. First, the thinness of the world rice market affects the sensitivity of rice price, which potentially leads to a change in the domestic price. Extension of explanations about the feature of the world rice market can be found in Chen and Saghaian (2016), Childs (2012), Dawe (2002), Slayton (2009), and many others. Further, many studies revealed that rice prices in developing countries were affected by the movement of prices in the international market (Ceballos, 2017; Malian et al., 2016; Minot, 2014). Thus, this condition potentially creates shocks that are harmful for price stabilization of rice in the domestic market; in the case of Indonesia, the increase in rice price affects inflation and the poverty rate. Second, as mentioned earlier, the rising rice price is the driving force behind the high inflation and poverty rates (McCulloch, 2008; Widiarsih, 2013). Since rice is the most important commodity in the Indonesian food basket, a spike in rice prices has an inflationary impact. McCulloch (2008) found that only around $25 \%$ of all farmers plant rice while most are net consumers of rice; consequently, they are vulnerable to the increase in rice prices. Expenditures for purchasing rice for the poor are almost $30 \%$ of their total income. Further, the weighted average of rice consumption in determining the poverty line is around $26 \%$. Thus, when the price of rice goes up, the number of poor people automatically increases (Cahyat, 2004; Pradhan et al., 2000).

A growing body of empirical research has examined the degree of market integration and how the price is transmitted among markets. Early work by Engle and Granger (1987) introduced the concept of co-integration in which nonstationary variables can have a linear relationship that moves together in the long run, while the short run exhibits a process of 
adjustment, the so-called error correction mechanism (ECM), which ensures that variables are corrected if they deviate from the long-run equilibrium. Previous studies in price transmission of agricultural markets generally assume the symmetry adjustment of the error in the long-run equilibrium that happens instantaneously and continuously in the short run (Bakucs and Fertõ, 2005; Minot, 2010; Rapsomanikis et al., 2006). However, certain characteristics attributed to the agricultural markets (e.g., market concentration and government intervention) lead to an asymmetric price response, which requires a different adjustment speed in the local market when there is an increase or a decrease in price in the reference market. Tifaoui and von Cramon-Taubadel (2017) argued that the adjustments from the equilibrium are asymmetric in nature, and described that the situations in which prices are linked by a long-run equilibrium relationship react differently depending on whether they are pushed too close together or pulled too far apart relative to the equilibrium. In other words, there exist different reactions for different shocks, depending on the magnitude and direction of the error. Particularly, the asymmetry in spatial markets is mainly because of market imperfection, and government intervention may slow the rate of transmission among markets (Abdulai, 2000; Rapsomanikis, 2006; Roberts et. al., 1994).

Further, empirical evidence highlights that price asymmetry arising from transaction cost potentially inhibits the continuous mechanism of price adjustment, as argued by previous studies (Balke and Fomby, 1997; Goodwin and Piggott, 2001; Meyer, 2004; Meyer and Taubadel, 2004). Balke and Fomby (1997) extensively explained how some mechanisms of price adjustment were possibly on-off mechanisms. They argued that this discontinuity may occur because the economic agent will not react if price deviation resulting from a shock is too small. Only when the deviation exceeds a certain critical value (threshold), the arbitrage activities present ensure the equalization of the price mechanism. Thus, the area where the price does not react to a certain shock is called a neutral band. Further, Goodwin and Piggot (2001) emphasized the importance of applying TVECM by finding that the adjustment of price is much faster in the threshold model than in VECM where the transaction cost is ignored. Meyer (2004) reinforced the importance of the threshold model application by comparing the results of the standard VECM and the TVECM in the European pig market. He found that the TVECM worked better in describing the price adjustments, and that the results considerably differed across both analyses. Using the VECM resulted in the interaction between German 
and Dutch markets correcting toward a long run-equilibrium, while using the TVECM showed that the price adjustment in the long run came only from the German market in the extreme regime. Thus, richer and more meaningful information was obtained through the TVECM than the VECM.

In the case of developing countries, research on market integration and price transmission also receives extensive attention. Among many others, Baquedano and Liefert (2014), Ceballos et al. (2017), and Minot (2011) applied VECM to examine the degree of market integration and price transmission. Meanwhile, considering the importance of transaction cost, Abdulai (2000), Balcombe et al. (2007), and Wondemu (2015) utilized TVECM to address the asymmetry in price transmission. In particular, the empirical evidence on the Indonesian rice market's integration with the international market showed mixed results. Jamora (2014) and Sharma (2003) did not find any evidence of co-integration between the domestic and the international market, while Greb et al. (2016), Quiroz and Soto (1995), and Warr (2008) showed the opposite. This study aims to improve our understanding of this price relationship by employing the average national weekly data published by the Ministry of Agriculture and Statistics Indonesia. Asymmetric and threshold models were used in this study to obtain a better picture of how the adjustment process takes place. Moreover, this study uses Thailand and Vietnam's price of $25 \%$ broken rice as the reference price since the widely imported rice is for food security and is rice mill with $25 \%$ broken rice, as stated in government regulations.

\subsection{Rice national supply balance and the polemic of import policy}

Indonesia is the third largest producer as well as consumer of rice after China and India (Jamora, 2014). Rice is the single commodity that is significantly important due to the socioeconomic, cultural, and political reasons involved in rice trade. Figure 3.1 illustrates the national supply balance of rice in 2010 and 2017. Based on the figure, rice production and consumption appears to have increased gradually over the entire period. The increase in production levels is slightly higher than that of consumption levels. Each year, the level of production always exceeds the consumption levels thus, creating a rice surplus balance over the last seven years. Accordingly, if that is the case, Indonesia does not need to import rice from other countries as the domestic needs can be fulfilled by its national production. 
Surprisingly, since the end of the oil boom (in the late 1980s), it is evident that Indonesian rice import has increased steadily except when the government imposed an import ban (in 2004 and 2008). This situation brings up questions on the accuracy of the rice supply balance published by the government for many years. Peter Rosner and McCulloch (2008) suggested that the source of inaccuracy of the production and consumption data was the overestimation of the production and underestimation of the consumption amounts. The overestimated level of production was mainly because the method of eye estimates were not reliable if used to measure the total harvested area, which was then used to estimate the amount of production in a certain period. On the other hand, rice consumption obtained from household surveys did not measure the rice consumed away from home and neglected the rice consumed by the food processing industry. This resulted in underestimations in the data on rice consumption.

Production and consumption data are key determinants to specify how much rice needs to be imported. However, with this inaccuracy, the government cannot rely on the production and consumption data. Instead, Peter Rosner and McCulloch (2008) concluded that the only reliable indicator to determine the appropriate amount of rice to be imported was price. This finding reconfirmed the relevance of understanding the movement of prices in one market as a consequence of changes in another market, that is, market integration and price transmission processes.

\subsection{The rice export policy in Thailand and Vietnam}

Thailand and Vietnam are the two biggest rice exporters in international markets (Dawe, 2002). Most ASEAN countries heavily depend on them to fulfill their rice import needs; Indonesia is no exception. This sub-section describes the economic conditions and policies influencing the export prices of these two exporting countries, which ultimately affects Indonesia as a rice importer.

Economic theory states that supply and demand determine the price of the commodity. In the international market, however, the price is also affected by the policies of the exporting 
countries. Given the thinness of the rice market, indicated by the fact that only $5 \%$ of rice produced in the world is traded by only a few players in the field, any shocks that occur within the exporting countries will be transmitted to the global market (Minot, 2010).

Liberalization of its agricultural sector has led Thailand to become one of the largest rice exporting countries globally since 1980 . Generally, rice policy is determined not only based on economic interests, but also politics. In the early period of intervention, tax became the government tool to gain revenue as it made it politically feasible for the government to finance its industrialization. In the following years, as the country became more industrialized, pressures from the farmers led to a more producer-oriented policy. In the period before Thailand became a part of the General Agreement on Tariffs and Trade, the government applied a price support policy to increase farmers' incomes as well as gain political support from the millers who benefited largely from this program. In the 21st century, the Thai government introduced mortgage and price pledge programs to stabilize farmers' incomes. Although these policies could be seen as a market distortion, they eventually guaranteed the incentive to grow rice to ensure that the rice supply is fulfilled, especially in terms of exports.

Regarding marketing systems, compared to other countries, Thailand's marketing system is rather efficient with only about a one-month storage period between harvest and wholesale. This short storage period is made possible by the Thai rice policies that allow international trade to play an essential role in the Thai rice economy. Due to the short storage time, seasons do not affect farm gate prices to a great extent and marketing costs are reduced (Dawe et al., 2008).

To reach the importers, brokers and commission agents act as intermediaries to connect millers and exporters. The main function of these brokers and commission agents is to help exporters to find rice of specific varieties and qualities. Unlike in the other countries, the share of brokers and commission agents at the local level is rather small. Thus, this guarantees that the highest margin goes to the farmers (Forssell, 2008). There are more than 100 exporting companies in Thailand, forming a very strong sector in the rice industry (Vanichanont, 2004). This efficient mechanism makes the international market price attractive. 
Considering the rice policy development in Vietnam, there have been major policy reforms related to the rice sector that have transformed Vietnam from a chronic rice importer in the 1980 s to the world's second largest rice exporter after Thailand, since 1989. The revolutionary rice policy was initiated in 1986 by the government; it brought major changes in the role of the market. Specifically, the government started to allow markets to play a greater role in the allocation of economic resources, which was marked by the decentralization of production responsibilities from collectives to individual farm households (Nelsen, 2003).

The Vietnamese government has been extending consistent support for the development of its rice export-oriented sector through its rice policies. Farm system reforms together with other supported policies that have been implemented over decades have succeeded in making Vietnam a key player in the international rice market. The Vietnamese government has been paying great attention to their irrigation systems; hence, the irrigated field and the harvested rice area continued to increase since 1976 (Nelsen, 2003). Improvements in irrigation increase the yield, which guarantees the supply of rice for domestic as well as export purposes.

Moreover, another influential policy was related to land reforms. Long before the liberalization era, the Vietnamese government controlled every aspect of the agricultural sector. Land was owned by the state, which determined how to cultivate the land and for what. As a step away from collective farming, a contract system was introduced in 1981 (Pingali and Xuan, 1992). Following subsequent reforms in 1988, 1993, and 1997, the farm household was recognized. Cooperative land was allocated to farming households with user rights for more than 10 years. In order to prevent a decline in total agricultural land or rice land, Vietnam has followed a strict policy of maintaining basic farmlands for grain production or a certain proportion of agricultural land for rice cultivation. Vietnamese government has set the goal of ensuring 3.8 million hectares of rice land by 2020 .

Related to the development of the rice export policies and parallel to its economic system reformation, rice export has changed from being controlled by export quotas to being supported by export subsidies. However, since Vietnam joined the World Trade Organization (WTO), all export subsidies have been abolished. With the commitment to WTO principles, all types of export subsidies in Vietnam were terminated in 2005. The only incentive that can be 
applied is providing a favorable loan interest rate for the export companies to buy rice for temporary stocking during the peak harvest season.

\subsection{Data and Estimation Strategy}

\subsubsection{Data}

We used secondary time series weekly data for the period 2010-2017. The Indonesian rice price data were obtained from the Statistics Indonesia (BPS), Ministry of Agriculture, and Ministry of Trade. The Thailand rice price data were published by Food and Agriculture Organization (FAO) and all data are in U.S. Dollars. A statistical summary of the rice prices is presented in Table 3.1.

(Insert table 3.1)

Table 3.1 describes the price series used in this study. As indicated, the price of rice in Indonesia was double that of Thailand and Vietnam, making import attractive to instantly fulfil domestic demand.

\subsubsection{Estimation Strategy}

\section{A. Symmetric Price Transmissions}

Two nonstationary variables that share a stationary long-run linear combination are said to be co-integrated (Engle and Granger, 1987). The prices of a homogeneous commodity in two locations, that is, the Indonesian market and the world market, are defined at time $t$ as $p_{t}^{d}$ and $p_{t}^{w}$, respectively, and are assumed to have a long-run equilibrium relationship of the form:

$$
p_{t}^{d}=\beta p_{t}^{w}
$$

In this case, $p^{w}$ represents Thailand (Vietnam) rice price and $\beta$ is the parameter to be estimated (note that all prices are used in log form in this study).

However, this condition may not ideally occur and hence, some adjustment needs to be made in short-run periods. This adjustment is called the error correction term (ECT) and takes the following form:

$$
E C T_{t-1}=\left(p_{t-1}^{d}-\beta p_{t-1}^{w}-\beta_{0}\right)
$$


This error term is assumed to correct the disequilibrium in the short run to ensure that the long-run relationship is restored.

Moreover, to examine the short-run and long-run relationships between the Indonesian rice market and the world market, the usual research strategy starts from an ECM by applying the Engle Granger two-step procedure, since the direction has been determined, that is, the international market will cause a change in price in the domestic market and not vice versa. In other words, we assumed that $p_{t}^{w}$ is weakly exogenous. However, for a robustness check, we also utilized the VECM by applying the Johansen method and looked for similar signals given by the two methods.

Engel Granger's (1987) test aims at examining the long run relationship between two I(1) variables. The author proposed a two-step procedure to co-integration analysis. In the first step, we examined the long run relationship by regression analysis. This process yielded the OLS residuals, which could be tested for being stationary using the ADF test with the MacKinnon (1991) critical values adjusted based on the number of variables. If co-integration held, the OLS estimator was said to be super-consistent and we could proceed to the second step of the procedure. The next step was the estimation of the ECM as in equation (2).

The Johansen co-integration test is generally based on the same concept as the Engel Granger test. However, the Johansen test is more complex than the latter as it allows several, say k, I(1) time series to be co-integrated. Thus, it facilitates the simultaneous examination of more than one direction of co-integration, which is akin to the VECM concept whereby the direction of co-integration can be reciprocal.

The VECM specification is as follows:

(1) $\left[\begin{array}{l}\Delta p_{t}^{d} \\ \Delta p_{t}^{w}\end{array}\right]=\left[\begin{array}{l}\varphi_{1} \\ \varphi_{2}\end{array}\right]+\left[\begin{array}{l}\alpha_{1} \\ \alpha_{2}\end{array}\right]\left[p_{t-1}^{d}-\beta p_{t-1}^{w}-\beta_{0}\right]+\sum_{j=1}^{k}\left[\begin{array}{ll}\delta_{1 j} & \rho_{1 j} \\ \delta_{2 j} & \rho_{2 j}\end{array}\right]\left[\begin{array}{l}\Delta p_{t-1}^{d} \\ \Delta p_{t-1}^{w}\end{array}\right]+\left[\begin{array}{c}\varepsilon_{1 t} \\ \varepsilon_{2 t}\end{array}\right]$

where $p_{t}^{d}$ is the rice price in the domestic market; $p_{t}^{w}$ is the rice price in the world market; $t$ is an index of time; $\alpha, \beta, \delta, \rho$, and $\varphi$ are parameters to be estimated; and $\varepsilon$ represents white noise errors. 
Based on the VECM, we expected that the world does not adjust to the Indonesian market but it is the latter that adjusts. Thus, we estimated the following single equation ECM in the second step of the Engle-Granger procedure:

(2) $\Delta p_{t}^{d}=\alpha\left(E C T_{t-1}\right)+\sum_{j=1}^{k} \delta_{j} \Delta p_{t-j}^{d}+\sum_{j-1}^{I} \rho_{j} \Delta p_{t-j}^{w}+\varepsilon_{t}$

\section{B. Asymmetric Price Transmissions}

The linear or symmetrical model of price transmissions assumes that any deviation from the long-run equilibrium is adjusted continuously regardless of the magnitude of the deviations. If this assumption of linearity held for the above models, it meant that all the parameters $(\alpha, \delta, \rho)$ were assumed to be constant during the study period. This assumption may be too restrictive considering that the dynamics of the socioeconomic conditions over varied lengths of study periods can change the magnitude of the parameters. This leads to considerable attention toward asymmetric price transmissions.

Peltzman (2000) examined 242 markets (77 consumer and 165 producer goods) in the United States and found evidence of asymmetric price transmissions in more than two-thirds of these markets. Thus, he concluded that asymmetry appears to be the nature of price transmissions. In other words, the symmetry price transmission is "nested" in a general asymmetric model as a special (restricted) case (Meyer and Cramon-Taubadel, 2004; Peltzman, 2000; Von Cramon-Taubadel and Meyer, 2000).

Specifically, the researcher favoring asymmetric price transmissions states that the adjustment parameters $(\alpha)$ may change in the long run. The magnitude of $\alpha$, representing the behaviors of the economic agents, will change depending on the sign of the error correction term (plus or minus). Different reactions of $\alpha$ are obtained when the price is squeezed (minus) or relaxed (plus). In our setting, we consider whether the domestic rice price responds more rapidly (or more slowly) to the increase in the international price than it does when there is a decrease. When the international price increases (decreases), the margin is squeezed (stretched) and the economic agents would react to these price movements. Generally, if there is an increase in price in the international market, the 
domestic market will follow faster than when there is a decrease. Thus, it is reconfirmed that $\alpha$ is asymmetric in nature.

To test whether there is a phenomenon of asymmetry in our case, we followed von CramonTaubadel (1998) in modifying the adjustment component (ECT) in a VECM as proposed by Granger and Lee (1989). This modification involves segmenting the error correction term into positive and negative components: $E C T^{+}=\max (0, E C T)$ and $E C T^{-}=\min (0, E C T)$. Accordingly, we estimated the following equation:

(3) $\Delta \mathrm{p}_{t}^{d}=\phi+\alpha^{+} E C T_{t-1}^{+}+\alpha^{-} E C T_{t-1}^{-}+\sum_{j=1}^{k} \delta_{j} \Delta p_{t-j}^{d}+\sum_{j-1}^{I} \rho_{j} \Delta p_{t-j}^{w}+\varepsilon_{t}$

To test for the phenomenon of asymmetry, we used an F test with the null hypothesis of symmetry $\left(H_{0}: \alpha^{+}=\alpha^{-}\right)$.

\section{Threshold Effect Model}

The threshold model emphasizes a certain value that divides a regime into at least two parts (at one threshold): upper regime and lower regime (Abdulai, 2002; Balke and Fomby, 1997; Enders and Granger, 1998). This is because after a certain value of deviation, the adjustment parameter acts differently (asymmetry). In this study, we apply one threshold model because the direction of the trade has been determined, that is, from the international to the domestic market. Hansen and Seo (2002) defined the two-regime threshold models as follows:

$$
\Delta x_{t}= \begin{cases}A_{1}^{\prime} X_{t-1}(\beta)+u_{t} & \text { if } w_{t-1}(\beta) \leq \gamma \\ A_{2}^{\prime} X_{t-1}(\beta)+u_{t} & \text { if } w_{t-1}(\beta)>\gamma\end{cases}
$$

where $X_{t}$ is an I(1) time series cointegrated with one cointegrating vector $(\beta) ; w_{t}(\beta)$ denotes the $\mathrm{I}(0)$ error correction term; and $\gamma$ is the threshold parameter. Alternatively, the expression above can be written as:

$$
\Delta x_{t}=A_{t}^{\prime} X_{t-1}(\beta) d_{1 t}(\beta, \gamma)+A_{2}^{\prime} X_{t-1}(\beta) d_{2 t}(\beta, \gamma)+u_{t}
$$

where:

$$
\begin{aligned}
& d_{1 t}(\beta, \gamma)=1\left(w_{t-1}(\beta) \leq \gamma\right. \\
& d_{1 t}(\beta, \gamma)=1\left(w_{t-1}(\beta)>\gamma\right.
\end{aligned}
$$


The threshold effect has content only if $0<P\left(w_{t-1} \leq \gamma\right)<1$; otherwise, the model simplifies to linear cointegration.

Hansen and Seo (2002) implemented the maximum likelihood estimation (MLE) of the threshold model involving a joint grid search over the threshold and the cointegrating vector. They also developed a test for the presence of a threshold effect with the null of linear cointegration. Hence, the model reduced to a conventional VECM. Following Hansen and Seo, in this setting, our estimated model was as follows:

Regime 1:

(4a) $\Delta p_{t}^{d}=\phi^{1}+\alpha^{1}\left(E C T_{t-1}\right)+\sum_{j=1}^{k} \delta_{j}^{1} \Delta p_{t-j}^{d}+\sum_{j-1}^{I} \rho_{j}^{1} \Delta p_{t-j}^{w}+\varepsilon_{t}^{1}$ if $E C T_{t-1} \leq \gamma$ Regime 2:

(4b) $\Delta p_{t}^{d}=\phi^{2}+\alpha^{2}\left(E C T_{t-1}\right)+\sum_{j=1}^{k} \delta_{j}^{2} \Delta p_{t-j}^{d}+\sum_{j-1}^{I} \rho_{j}^{2} \Delta p_{t-j}^{w}+\varepsilon_{t}^{2}$ if $E C T_{t-1}>\gamma$

\subsection{Empirical Results}

\subsubsection{Stationarity and co-integration tests}

To test the stationarity of the variables, we used the Augmented Dickey Fuller (ADF) unit root test $(1979,1981)$ with the null hypothesis that the variable has a unit root (non-stationary). Accordingly, we concluded that the time series variables were non-stationary. If the tests showed that the variables were individually integrated, that is, I(1), the next step would be the test for stationarity in differenced form. We expected to obtain stationary variables and to proceed to the next step, that is, the test of co-integration. The results are presented in Table 3.2.

(Insert table 3.2)

As can be observed from table 3.2, all the series are stationary in the first difference. Thus, we proceeded to the co-integration test. In this test, we checked whether the series were linearly co-integrated using lag 3 for the Indonesia-Thailand pair and lag 2 for the IndonesiaVietnam pair, as indicated by the lag selection criterion (we used AIC for the IndonesiaThailand pair and BIC for the Indonesia-Vietnam pair as these provided the best results).

(Insert Table 3.3) 
Table 3.3 summarizes the results of the co-integration tests. The results suggest that we may reject the null hypothesis of no co-integration between the domestic and international prices, but fails to reject the null hypothesis of one co-integration relationship.

\subsubsection{Symmetric, asymmetric, and threshold error correction model}

The short-run and long-run dynamics are shown in the ECM. We investigated whether the adjustment process is symmetric or asymmetric, and proceeded with the investigation of the threshold.

To examine the symmetric price transmission, we utilized the VECM for both pairs. The results are represented in Table 3.4.

(Insert Table 3.4)

Table 3.4 shows the long-run and short-run relationships between the domestic and the international market (Thailand for model 1 and Vietnam for model 2). Lag 3 and 2 are chosen by the $\mathrm{AIC}$ and $\mathrm{BIC}$ for models one and two, respectively. Related to the long-run relationships represented in Table 3.4a, the Vietnam price significantly affected the movement of the domestic price with a relatively high magnitude. The movement between these two prices was almost one to one; a $1 \%$ price increase in Vietnam would cause a $0.97 \%$ increase in Indonesia's domestic price. On the other hand, Thailand price did not significantly influence a change in the domestic price in the long run.

For the short-run dynamics, the error correction terms showed that the estimated adjustment parameters were significantly different from zero for both models, although the magnitude was very small. For pair one, Indonesia-Thailand, the estimated adjustment parameter shows that for every period, only $1 \%$ of the shocks are corrected continuously (Table 3.4a). While for pair two, Indonesia-Vietnam, the adjustment process comes not only from Indonesia but also from Vietnam. This is surprising because Vietnam is also a big rice exporter and the amount of rice exported to Indonesia is relatively small. Altogether, the correction was around $5 \%$ in every period; thus, it would take a very long period to restore the equilibrium between the prices. This implies that the co-integration between the domestic and 
international market (for both markets) was weak. In other words, the movement of domestic price resulting from the world price shock, toward the equilibrium is slow. The slow price transmission from the world market to the domestic market, particularly among developing countries, was also observed in other studies (Baquedano and Liefert, 2014; Ceballos et al., 2017; Minot, 2011). In addition, both models showed that, in the short run, the fluctuation in the international market did not influence the price change in the domestic market. In other words, in the short run, the domestic market dynamics were mainly influenced by its own price in the past period.

To proceed to the asymmetric price transmission, we first generated an error correction term (ECT) for both models by saving the residual from the long-run regressions. Then, we split the ECT into $E C T^{+}$and $E C T^{-}$. The following step involved running the regression and testing whether the coefficient of both ECTs were significantly different from each other. The results are presented in Table 3.5.

(Insert Table 3.5)

Table 3.5 presents the estimation results of asymmetric models (equation 3). For both models, the $\mathrm{F}$ statistics confirmed the rejection of the null hypothesis of symmetric price transmission at the $10 \%$ significance level. Testing for the equality of the positive and negative ECT coefficients showed that the coefficient of $\mathrm{ECT}^{+}$and $\mathrm{ECT}^{-}$significantly differed from each other. Thus, it is confirmed that the adjustment process is not the same when the shocks that make both prices are too far apart or too close together.

Both models indicated that the estimated asymmetric models signify that positive deviations of the domestic rice price from the long run-equilibrium are corrected by a factor of less than $1 \%$ per week, and the corresponding coefficient, $\alpha^{+}$, shows no significant difference from zero. On the contrary, negative deviations are corrected by $2 \%$ for model one and $3 \%$ for model two per week. The corresponding coefficient, $\alpha^{-}$, is significantly different from zero at a $1 \%$ significance level. These results indicate that the economic agents tend to react to negative deviations than to positive ones. In other words, when the margin is squeezed (negative deviations), the response of the economic agents to return to the equilibrium 
position is faster than when the margin is stretched (positive deviations). The squeezed margin occurs when the international price increases and the stretched margin when the opposite occurs. Accordingly, the correction of an increase in the international market price is significantly faster than in the case of a decrease, which is almost no reaction.

Further, we tested whether there was a threshold behavior in the series by applying the Hansen and Seo test. The results are shown in Table 3.6.

(Insert Table 3.6)

The test statistics and p-values indicated in table 3.6 are greater than the critical values for the case of pair one (Indonesia-Thailand) and the opposite applies for the second pair of countries (Indonesia-Vietnam). Hence, we rejected the null hypothesis of linear cointegration and concluded that there is a threshold behavior in the error correction mechanism only for pair one. The TVECM is presented in the following table.

(Insert Table 3.7)

Table 3.7 illustrates the TVECM results for pair one (Indonesia-Thailand) only, as we cannot reject the null hypothesis of linear transmission for pair two (Indonesia-Vietnam). We focused only on the column for Indonesia-Thailand as its direction has been determined, and only the domestic economy makes the adjustment and not the international one. The Thailand-Indonesia portion is presented to complement and reconfirm the aforementioned argument shown by the ECTs for both regimes in the Thailand-Indonesia column, indicating that the coefficient of ECT is negligible and not significantly different from zero.

As we can see in Table 3.7, the threshold parameter $(\gamma)$ is 0.093 . Based on this value, regime 1 is defined from the weekly observations that deviate from the long-run equilibrium below 9.3\%, while regime 2 can be identified by the prices deviating from the long run above $9.3 \%$. Observing the adjustment parameters in both regimes, the threshold model shows no significant adjustment to the deviations from the long-run equilibrium in regime 1 . These results confirm the threshold model, according to which transaction costs retard long-run 
price adjustments between the two markets. Only when the deviations from the long-run equilibrium exceed the critical threshold value, that is regime 2, adjustment would occur. Regime 1 contained $58 \%$ of the observations where no adjustment occurs, and the remaining observations are in regime 2 , where adjustments occur. This former showed a higher deviation from the long-term equilibrium.

Estimated coefficients in regime 1 and regime 2 show that only the domestic lagged price change had a significant effect on its own price change in the short run, while the estimated adjustment parameter in regime 2 shows that only $6 \%$ of the deviations from the long-run equilibrium were corrected each week. The concluding result is similar to that of the linear model, in that the two markets are co-integrated but the adjustment toward equilibrium is weak. However, the threshold model confirms the non-linearity of adjustments as indicated in the asymmetric transmission test as well.

\subsubsection{Some policy implications}

Indonesia is the largest consumer of rice in the ASEAN and depends on the world market to fill the gap between the amount of rice it produces and its consumption needs. The international rice market is concentrated in a few large exporting countries. Recently, Thailand and Vietnam have become the key players for the rice type $25 \%$ broken, which is needed to implement a domestic stabilization policy. Since the export price is not solely dependent on the supply and demand in the marketplace, the economic and political background of the exporting countries should be considered triggers of export price fluctuations. The price in the domestic economy is affected by whether the degree of integration between the domestic and the world market is high or low.

The aforementioned results suggest that there is a weak/low price transmission between the domestic and the international markets (Thailand and Vietnam) as seen from the coefficient of ECT. In other words, the shocks happening in the international markets have only a little influence on the price dynamics in the domestic markets. Thus, in the short run, the international markets are reliable rice suppliers for the domestic economy to attain rice price stabilization. 
Further, the sluggishness of the error correcting process is plausibly due to the absence of arbitrage as in the case of common trade, whereby economic agents freely react when there is a price incentive. Rice import is highly regulated by the government with the import monopoly held by BULOG. The Indonesian government allows import only to stabilize rice prices. Thus, the government does not necessarily respond to the incentives that exist in the international market. The determination of when and how much rice is to be imported is by design (i.e., not determined by the market mechanism), concerning mainly the amount of rice needed for stabilization.

The thinness of the world rice market can bring a shock to the domestic economy. However, McCulloch and Timmer (2008) revealed that the world rice market is relatively stable and competitive (Chen and Saghaian, 2016). In addition, the result of this study confirms the low price transmitted from the world to the domestic economy, thereby reaffirming that Indonesia can rely on the world market as its rice supplier. Moreover, with the implementation of Thailand's price pledge program, which increases the export price of Thai rice, importers, especially Indonesia, inevitably switch to Vietnamese rice, which is much cheaper. This is plausible because Indonesia could consider the rice type $25 \%$ broken from Thailand and Vietnam as perfect substitutes. Hence, the cheaper of the two rice prices from Thailand or Vietnam would be favored.

The results of asymmetric price transmission can be found by splitting the ECT as well as observing the threshold effect. It is stated that the squeezed margin is adjusted faster than the stretched margin. In a more general case, this can be rationalized as follows: sellers tend to maintain their margins for as long and as much as they can. Thus, an increase in the international price that could decrease their margin obtains a faster response. On the other hand, there is a delay in responding to a decrease in international price, as this can prolong the duration for which they can obtain higher margins. This also indicates that the domestic market is an oligopoly or monopoly. However, the case of Indonesia is different because the government's aim in drafting the import policy is not to optimize profits but to stabilize prices in the domestic economy. This finding implies that the domestic price is more responsive to the increase in the international price than to its decrease. Thus, the government can anticipate the increase in the domestic price (i.e., by selling the rice in the market at a cheaper 
price) whenever there is a sign that the international price may increase. The weakness of this high cost policy is that there needs to be an adequate stock of rice anytime the government needs to influence the domestic market. The asymmetric adjustment is also confirmed by the TVECM with a threshold value of $9.3 \%$ for the Indonesia-Thailand price pair.

\subsection{Conclusion}

Many studies have highlighted the importance of studying market integration and price transmission from the international to the domestic market due to its effect on the domestic economy. Numerous studies have also explored this relationship in the context of the Indonesian rice market; however, their results are inconclusive.

This study aims to examine the price transmission behavior of the international markets, represented by Thailand and Vietnam, to the domestic market, in this case, Indonesia. Weekly data from 2010 to 2017 are employed in this study. We utilized VECM and TVECM to observe symmetric and asymmetric as well as the threshold effect of the short-run adjustment process.

The VECM results showed that the speed of adjustment for each county pair is very small but significant, indicating that it takes a long time for the shock to be completely corrected. In the case of asymmetry, the results suggest that there are asymmetric behaviors for both pairing countries (Indonesia-Thailand and Indonesia-Vietnam) as shown by the significant difference in adjustments when squeezed and stretched margins occur; yet, the magnitudes are small. For the threshold model, only the Indonesia-Thailand pair's ECT showed a different speed of adjustment when the deviation from the long-run equilibrium exceeded the threshold value of $9.3 \%$. In conclusion, both symmetric and asymmetric models confirmed that the domestic market was co-integrated with the international market; however, the price transmissions between the two were weak as shown by the magnitude of the ECT.

This study does not consider the market concentration in the domestic economy as a possible reason for the sluggishness of the ECT to adjust to the equilibrium with the international price. We recommend this as an avenue for further research. 


\subsection{Appendix of chapter three}

Tables and Figures

Table 3.1: Summary Statistics for the Investigated Price Variables in USD

\begin{tabular}{lrrrr}
\hline Price Series & Mean & $\begin{array}{l}\text { Standard } \\
\text { Deviation }\end{array}$ & Minimum & Maximum \\
\hline Indonesia $^{1}$ & $9,481.49$ & $1,341.945$ & $6,565.273$ & $12,048.4$ \\
Thailand $^{2}$ & $5,074.592$ & 457.517 & $3,862.972$ & $6,007.642$ \\
Vietnam $^{2}$ & $4,212.731$ & 532.466 & $2,746.466$ & $5,217.643$ \\
\hline
\end{tabular}

'Source: 1. Statistics Indonesia and Ministry of Trade; 2. USDA

Table 3.2. Unit Root Test of the Price Series

\begin{tabular}{lrrrr}
\hline \multirow{2}{*}{ Prices* } & \multicolumn{2}{c}{ Level } & \multicolumn{2}{c}{ First Difference } \\
\cline { 2 - 5 } & t-statistics & p-value & t-statistics & \multicolumn{1}{c}{ p-value } \\
\hline Indonesia & & & & \\
- With constant & -2.01277 & 0.2815 & -6.51959 & $6.105 e-09$ \\
- With constant and trend & -2.32345 & 0.4205 & -5.91615 & $1.85 e-06$ \\
Thailand & & & & \\
- With constant & -2.69477 & 0.07487 & -12.2117 & $2.134 \mathrm{e}-26$ \\
- With constant and trend & -2.75095 & 0.2159 & -12.2038 & $2.378 \mathrm{e}-29$ \\
Vietnam & & & & \\
- With constant & -1.95156 & 0.3088 & -18.3218 & $2.622 \mathrm{e}-34$ \\
- With constant and trend & -3.41311 & 0.04957 & -18.3094 & $8.152 \mathrm{e}-40$ \\
\hline
\end{tabular}

* Prices are in the log form 
Table 3.3. Johansen Co-Integration Test Results

\begin{tabular}{ccccccc}
\hline \multirow{2}{r}{} & \multicolumn{3}{c}{ Indonesia - Thailand } & \multicolumn{3}{c}{ Indonesia - Vietnam } \\
\cline { 2 - 7 } & Eigenvalue & Test Statistics & p-value & Eigenvalue & Test Statistics & p-value \\
\hline 0 & 0.032842 & 20.965 & 0.0382 & 0.043187 & 25.450 & 0.0075 \\
1 & 0.017099 & 7.1403 & 0.1222 & 0.017031 & 7.1286 & 0.1228 \\
\hline
\end{tabular}

Table 3.4. Results of Vector Error Correction Model

a. Domestic - World

\begin{tabular}{clclc}
\hline & \multicolumn{2}{c}{ Indonesia-Thailand } & \multicolumn{2}{c}{ Indonesia-Vietnam } \\
\cline { 2 - 5 } Coefficient & \multicolumn{1}{c}{ Estimate } & \multicolumn{1}{c}{ SE } & \multicolumn{1}{c}{ Estimate } & SE \\
\hline Long Run & & & & \\
$\beta_{0}$ & 6.7759 & 5.5735 & 0.9301 & 1.6097 \\
$\beta_{1}$ & 0.3013 & 0.6582 & $0.9731^{* * *}$ & 0.1897 \\
& & & & \\
Short Run & & & & \\
$\delta_{1}$ & $-0.4851^{* * *}$ & 0.0483 & $-0.4012^{* * *}$ & 0.0445 \\
$\delta_{2}$ & $-0.1764^{* * *}$ & 0.0485 & - & - \\
$\rho_{1}$ & 0.0170 & 0.0367 & 0.0045 & 0.1563 \\
$\rho_{2}$ & 0.0026 & 0.0365 & - & - \\
$\alpha$ & $-0.0104^{* * *}$ & 0.0030 & $-0.0210^{* * *}$ & 0.0065 \\
\hline
\end{tabular}

b. World - Domestic

\begin{tabular}{clccc}
\hline & \multicolumn{2}{c}{ Thailand-Indonesia } & \multicolumn{2}{c}{ Vietnam-Indonesia } \\
\cline { 2 - 5 } Coefficient & \multicolumn{1}{c}{ Estimate } & \multicolumn{1}{c}{ SE } & \multicolumn{1}{c}{ Estimate } & SE \\
\hline$\delta_{1}$ & 0.0916 & 0.065 & -0.0093 & 0.0759 \\
$\delta_{2}$ & -0.031 & 0.065 & - & - \\
$\rho_{1}$ & $0.0815^{*}$ & 0.049 & $0.1165^{* *}$ & 0.0488 \\
$\rho_{2}$ & $0.1119^{* *}$ & 0.049 & - & - \\
$\alpha$ & 0.0039 & 0.004 & $0.0315^{* * *}$ & 0.0112 \\
\hline
\end{tabular}


Table 3.5. Results of the Asymmetric ECM

\begin{tabular}{|c|c|c|c|c|}
\hline \multirow[b]{2}{*}{ Coefficient } & \multicolumn{2}{|c|}{ Indonesia-Thailand } & \multicolumn{2}{|c|}{ Indonesia-Vietnam } \\
\hline & Estimate & SE & Estimate & SE \\
\hline$\delta_{1}$ & $-0.4831 * * *$ & 0.0488 & $-0.4086^{* * *}$ & 0.0449 \\
\hline$\delta_{2}$ & $-0.1720 * * *$ & 0.0488 & - & - \\
\hline$\rho_{1}$ & 0.0202 & 0.0370 & 0.0075 & 0.0286 \\
\hline$\rho_{2}$ & 0.0064 & 0.0368 & - & - \\
\hline$\alpha^{+}$ & 0.0007 & 0.0082 & -0.0025 & 0.0114 \\
\hline$\alpha^{-}$ & $-0.0190 * * *$ & 0.0064 & $-0.0304 * * *$ & 0.0092 \\
\hline
\end{tabular}

Test of Linear Restriction

$\begin{array}{lclc}\text { F statistic } & 3.559 & \text { F statistic } & 3.584 \\ \text { p-value } & 0.0599 & \text { p-value } & 0.0590\end{array}$

Table 3.6. Test of Linear Co-Integration versus Threshold Co-Integration by Hansen and Seo (2002)

a. Indonesia-Thailand

Test statistic

p-value

Cointegrating value:

Critical values:

$0.90 \%$

$0.95 \%$

7.2342

15.79145 (Maximized for threshold value: 124.1566)

$0.0000 \quad$ (Fixed regressor bootstrap)

13.6177 (estimated under restricted linear model)

b. Indonesia-Vietnam

Test statistic

p-value

Cointegrating value:

Critical values:

$\begin{array}{rrr}0.90 \% & 0.95 \% & 0.99 \% \\ 28.359 & 28.775 & \end{array}$

19.7365
0.9
-1.2191
$0.99 \%$

(Maximized for threshold value: -1.092)

(Fixed regressor bootstrap)

(estimated under restricted linear model) 
Table 3.7. The results of the Threshold VECM

\begin{tabular}{|c|c|c|c|c|}
\hline \multirow[b]{2}{*}{ Coefficient } & \multicolumn{2}{|c|}{ Indonesia-Thailand } & \multicolumn{2}{|c|}{ Thailand-Indonesia } \\
\hline & Estimate & SE & Estimate & SE \\
\hline \multicolumn{5}{|l|}{ Regime 1} \\
\hline$\delta_{1}$ & $-0.8978 * * *$ & $1.3 e-27$ & 0.0006 & 0.9955 \\
\hline$\delta_{2}$ & $0.8557 * * *$ & $3 e-06$ & -0.0701 & 0.7844 \\
\hline$\rho_{1}$ & -0.0075 & 0.8559 & 0.0004 & 0.9945 \\
\hline$\rho_{2}$ & 0.0111 & 0.7894 & $0.1999 * * *$ & 0.0008 \\
\hline$\alpha$ & 0.0048 & 0.4602 & 0.0140 & 0.1287 \\
\hline \multicolumn{5}{|l|}{ Regime 2} \\
\hline$\delta_{1}$ & $-0.3112 * * *$ & $3.1 \mathrm{e}-07$ & 0.1433 & 0.092 \\
\hline$\delta_{2}$ & $-0.1720 * * *$ & 0.0488 & -0.0135 & 0.8527 \\
\hline$\rho_{1}$ & 0.0055 & 0.9296 & $0.2904 * * *$ & 0.001 \\
\hline$\rho_{2}$ & 0.0545 & 0.3715 & -0.0879 & 0.3092 \\
\hline$\alpha$ & $-0.0648 * *$ & 0.0011 & 0.0328 & 0.2393 \\
\hline \multicolumn{2}{|c|}{ Threshold value } & & 0.09263 & \\
\hline \multicolumn{5}{|c|}{ Percentage of observations in each regime } \\
\hline \multicolumn{2}{|c|}{ - $\quad$ Regime 1} & & \multicolumn{2}{|l|}{$58.4 \%$} \\
\hline \multicolumn{2}{|c|}{ - $\quad$ Regime 2} & & $41.6 \%$ & \\
\hline
\end{tabular}


Figure 3.1. The quantity of rice production, consumption, and imports from $2010-2017$ (in million metric tons)

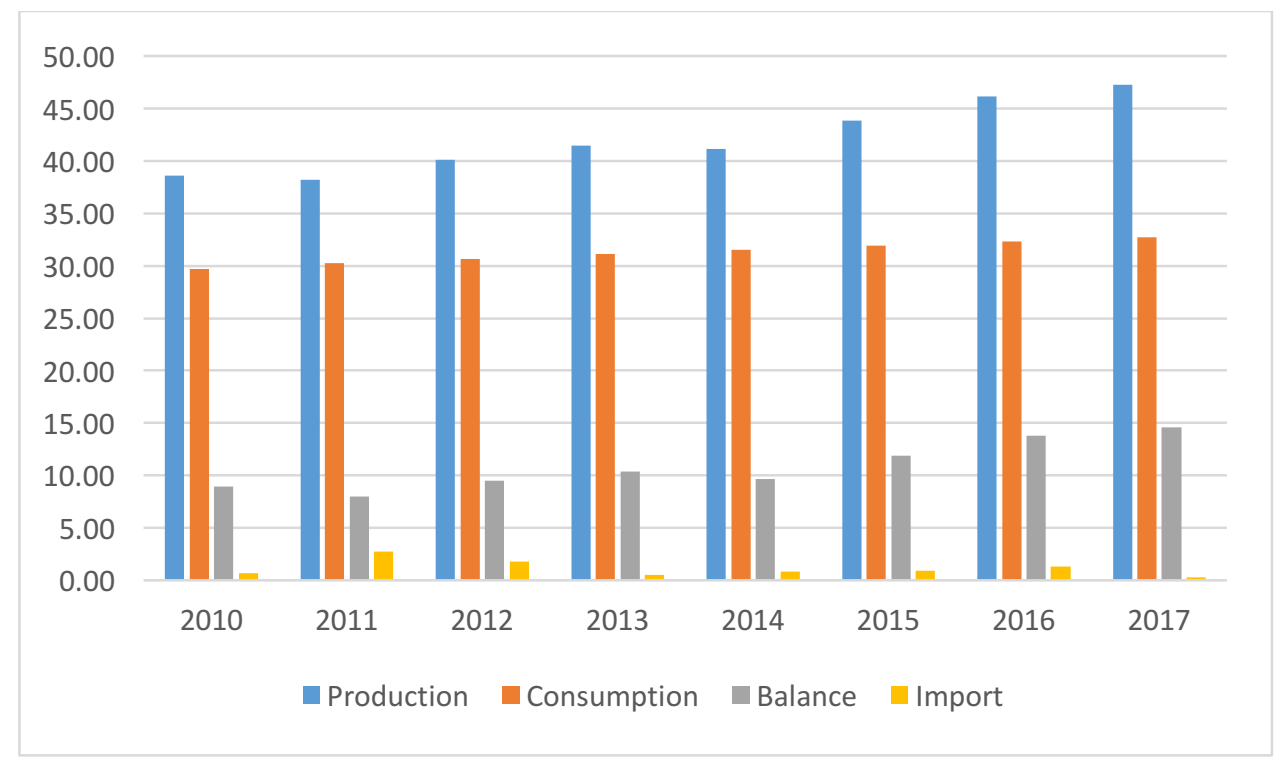

Source: Statistics Indonesia (2018) 


\section{CHAPTER FOUR}

\section{CONCLUSION}

Being the fourth largest populated country in the world, Indonesia can potentially attain its economic and development targets with its abundant labor force. At the same time, the problem of food security is an impediment threatening the country's economic performance. This dissertation addressed two different aspects related to the food security problem in Indonesia, particularly from the aspect of food accessibility and availability. This final chapter briefly concludes and summarizes the policy implications and potential directions for future research on the two assessments presented.

The first segment dealt with the assessment of undernutrition vulnerability, where we highlighted the importance of assessing the probability of being nutrient deficient in the future as a complement to considering the current nutritional status. The empirical investigation was conducted by employing the Just and Pope (1979) method to estimate the vulnerability rate toward the per-capita intake of calories, protein, calcium, and iron across households. The data were obtained from a socioeconomic survey conducted in 2013 in East Java, Indonesia. By exploiting the households' socioeconomic characteristics and district specific information, this study found that half of the sampled population were vulnerable to nutrition deficiencies in terms of energy, protein, calcium, and iron consumptions. Furthermore, one-third from around $46 \%$ food secured sample households were found to be vulnerable to calorific under-consumption while approximately $14 \%$ out of $41 \%, 13 \%$ out of $50 \%$, and $6 \%$ out of $60 \%$ households with nourished nutritional statuses were found to be vulnerable to inadequate intake of protein, calcium, and iron, respectively. 
By creating the vulnerability index, the results revealed that income was the most prominent indicator determining the sufficiency of nutrient intake. Moreover, education also played a role in combating under-consumption of food as well as in the asset coping capacity (i.e., motorcycle ownership and cement floor area in the households). In terms of district-specific variables, the number of clinics and markets played a positive role in decreasing the vulnerability rate to undernutrition.

These findings lead to suggestions for well-targeted cash transfer programs aiming to increase households' purchasing power, especially to buy nutritious food. Further, it is important to develop education specific to knowledge of nutrition to have a better understanding of the relationship between food and health. These suggestions can be implemented by educating school children, conducting campaigns in public facilities such as hospitals, and integrating service stations.

In addition, some of the limitations of this study provide room for improvement in future research. We were unable to capture the distribution of food within a household, which could yield other important findings related to the dual burden of malnutrition in this region. In addition, we also failed to capture food consumed away from home, which potentially could lead to other important findings. The unavailability of panel data also impeded any improvement in prediction accuracy of the vulnerability index that we developed.

Moreover, food accessibility cannot be separated from food availability, which is reflected in price of the food itself. The price of rice for Indonesians is a crucial factor as food security can be translated as rice security. Hence, the second segment aimed at examining the transmission of the international rice price (taking the rice price of Thailand and Vietnam as the reference price) movements to the domestic price. As a large-rice importing country, Indonesia is prone to shocks from the international market, given the thin feature of the world rice market. Thus, employing weekly data from 2010 to 2017 and the VECM and TVECM, we observed the symmetric and asymmetric as well as threshold effects of the short-run adjustment process. 
The findings revealed that there was low price transmission from the international to the domestic rice market, with asymmetric adjustment of error. We found the threshold effect only for the Indonesia-Thailand price pair. One of the implications of the low market integration is that the shocks occurring in the international markets have only a slight impact on the domestic economy. Thus, in the short run, the international market can be a reliable source of supply for the rice needed for price stabilization. However, low price transmission is also a sign of inefficiency of the rice market in the domestic economy and that the domestic economy cannot benefit from the price incentives in the world market. This may possibly be because the costly government intervention results in an immediate pseudo-tranquil condition but can potentially be the cause of the misallocation of economic resources in the long term. In the case of asymmetry, whereby the domestic price is more responsive to an increase rather than a decrease in the international price, the government can adopt an anticipation strategy by conducting a market operation to muffle the price increase, that is, by selling the rice in the market at a cheaper price. The weakness of this high cost policy is that there needs to be an adequate stock of rice anytime the government needs to influence the domestic market. 


\section{BIBLIOGRAPHY}

Abdullah, A. B., Ito, S., \& Adhana, K. (2006, March). Estimate of rice consumption in Asian countries and the world towards 2050. In Proceedings for Workshop and Conference on Rice in the World at Stake (Vol. 2, pp. 28-43).

Abdulai, A. (2000). Spatial price transmission and asymmetry in the Ghanaian maize market. Journal of development economics, 63(2), 327-349.

Abdulai, A. (2002). Using threshold cointegration to estimate asymmetric price transmission in the Swiss pork market. Applied Economics, 34(6), 679-687.

Afkar, R., \& Matz, J. (2015). Cash transfer, In-Kind, or both? Assessing the Food and Nutrition Security Impacts of Social Protection Programs in Indonesia. In 2015 Conference, August 9-14, 2015, Milan, Italy (No. 210936). International Association of Agricultural Economists.

Amelia, R., \& Purhadi, P. (2012). Pemodelan Jumlah Balita Gizi Buruk di Jawa Timur dengan Geographically Weighted Poisson Regression. Jurnal Sains dan Seni ITS, 1(1), D290D295.

Arora, Suchit. (2001). Health, human productivity, and long-term economic growth. The Journal of Economic History 61.03: 699-749.

Arif, M., \& Wicaksani, R. A. (2017). Ketimpangan Pendapatan Propinsi Jawa Timur dan Faktorfaktor yang Mempengaruhinya. URECOL, 323-328.

Atmarita, A. (2005). Nutrition problems in Indonesia. Penelitian Gizi dan Makanan (The Journal of Nutrition and Food Research), 28(2).

Bakucs, L. Z., \& Fertõ, I. (2005). Marketing margins and price transmission on the Hungarian pork meat market. Agribusiness, 21(2), 273-286.

Balcombe, K., Bailey, A., \& Brooks, J. (2007). Threshold effects in price transmission: the case of Brazilian wheat, maize, and soya prices. American Journal of Agricultural Economics, 89(2), 308-323.

Balke, N. S., \& Fomby, T. B. (1997). Threshold cointegration. International economic review, 627-645.

Baquedano, F. G., \& Liefert, W. M. (2014). Market integration and price transmission in consumer markets of developing countries. Food Policy, 44, 103-114. 
Biederlack, L., \& Rivers, J. (2009). Comprehensive Food Security \& Vulnerability Analysis (CFSVA): Ghana. United Nations World Food Programme.

Berlingieri, F. 2009. Fighting child malnutrition in Indonesia: evaluation of two recent pro-poor policies. Faculty of Economics Master of Science in Economics and Social Sciences Università Commerciale.

Block, S. A., Masters, W. A., \& Bhagowalia, P. (2012). Does child undernutrition persist despite poverty reduction in developing countries? Quantile regression results. The Journal of Development Studies, 48(12), 1699-1715.

Bogale, A. (2012). Vulnerability of smallholder rural households to food insecurity in Eastern Ethiopia. Food Security, 4(4), 581-591.

Burg, J. (2008). Measuring populations' vulnerabilities for famine and food security interventions: the case of Ethiopia's Chronic Vulnerability Index. Disasters, 32(4), 609630.

Cahyat, A. (2004). Bagaimana kemiskinan diukur?: beberapa model pengukuran kemiskinan di Indonesia (No. CIFOR Governance Brief no. 2, p. 8p). CIFOR, Bogor, Indonesia.

Capaldo, J., Karfakis, P., Knowles, M., \& Smulders, M. (2010). A Model of Vulnerability to Food Insecurity.

Ceballos, F., Hernandez, M. A., Minot, N., \& Robles, M. (2017). Grain price and volatility transmission from international to domestic markets in developing countries. World Development, 94, 305-320.

Chaudhuri, S., Jalan, J., \& Suryahadi, A. (2002). Assessing household vulnerability to poverty from cross-sectional data: A methodology and estimates from Indonesia (Vol. 102, p. 52). Discussion paper.

Chen, B., \& Saghaian, S. H. (2016). Market integration and price transmission in the world rice export markets. Journal of Agricultural and Resource Economics, 41(3), 444.

Childs, N. (2012). Rice outlook. USDA-ERS. Washington DC.

Christiaensen, L. J., \& Boisvert, R. N. (2000). On measuring household food vulnerability: Case evidence from Northern Mali. Ithaca, NY: Department of Agricultural, Resource, and Managerial Economics, Cornell University.

Cox, David N., et al. (1998). Take Five, a nutrition education intervention to increase fruit and vegetable intakes: impact on consumer choice and nutrient intakes. British Journal of Nutrition 80.2: 123-131.

Dawe, D. (2002). The changing structure of the world rice market, 1950-2000. Food Policy, $27(4), 355-370$. 
Departemen Kesehatan Republik Indonesia. (2013). Riset kesehatan dasar. Jakarta: Badan Penelitian dan Pengembangan Kesehatan Departemen Kesehatan Republik Indonesia.

Devereux, S. (2006). Distinguishing between chronic and transitory food insecurity in emergency needs assessments. World Food Program, Emergency Needs Assessment Branch.

Dewan Ketahanan Pangan, Kementerian Pertanian, and World Food Programme. (2015). Food Security and Vulnerability Atlas of Indonesia 2015. Dewan Ketahanan Pangan, Kementerian Pertanian, and World Food Programme (WFP). http://documents.wfp.org/stellent/groups/public/documents/ena/wfp276246.pdf

Dickey, D. A., \& Fuller, W. A. (1979). Distribution of the estimators for autoregressive time series with a unit root. Journal of the American statistical association, 74(366a), 427431.

Dickey, D. A., \& Fuller, W. A. (1981). Likelihood ratio statistics for autoregressive time series with a unit root. Econometrica: Journal of the Econometric Society, 1057-1072.

D'Avanzo, Barbara, et al. (1997). Nutrient intake according to education, smoking, and alcohol in Italian women.

Ecker, O., Al-Riffai, P., Breisinger, C., \& El-Batrawy, R. (2016). Nutrition and economic development: Exploring Egypt's exceptionalism and the role of food subsidies. Intl Food Policy Res Inst.

Enders, W., \& Granger, C. W. J. (1998). Unit-root tests and asymmetric adjustment with an example using the term structure of interest rates. Journal of Business \& Economic Statistics, 16(3), 304-311.

Engle, R. F., \& Granger, C. W. (1987). Co-integration and error correction: representation, estimation, and testing. Econometrica: journal of the Econometric Society, 251-276.

FAO, A. (2008). An introduction to the basic concepts of food security. Food Security Information for Action. Practical Guides.

FAO. (2015). Penelitian FAO: 19,4 Juta Penduduk Indonesia Masih Alami Kelaparan.. http://www.voaindonesia.com/a/pemelitian-fao-sembilan-belas-koma-empat-jutapenduduk-indonesia-masih-mengalami-kelaparan/2817021.html

FAO. (2013). National nutrition strategy paper of Indonesia. FAO/WHO. http://www.fao.org/3/a-at618e.pdf.

Fogel, R. W. (2004). Health, nutrition, and economic growth. Economic Development and Cultural Change, 52(3), 643-658.

Forssell, S. (2009). Rice price policy in Thailand. 
Francisco, S. R., Mataia, A. B., Eusebio, A. M., Sanguyo, E. B., Constantino, M. A. S., Causon, E. D., ... \& Sombillia, M. (2013). Per capita rice consumption in the Philippines: reasons behind increases. Philippine Journal of Crop Science, 38(1), 33-42

Granger, C. W., \& Lee, T. H. (1989). Investigation of production, sales and inventory relationships using multicointegration and non-symmetric error correction models. Journal of applied econometrics, 4(S1), S145-S159.

Goodwin, B. K., \& Piggott, N. E. (2001). Spatial market integration in the presence of threshold effects. American Journal of Agricultural Economics, 83(2), 302-317.

Greb, F., Jamora, N., Mengel, C., Cramon-Taubadel, V., \& Würriehausen, N. (2016). Price transmission from international to domestic markets.

Hansen, B. E., \& Seo, B. (2002). Testing for two-regime threshold cointegration in vector errorcorrection models. Journal of econometrics, 110(2), 293-318.

Hartini, T. N. S., Winkvist, A., Lindholm, L., Stenlund, H., Persson, V., Nurdiati, D. S., \& Surjono, A. (2003). Nutrient intake and iron status of urban poor and rural poor without access to rice fields are affected by the emerging economic crisis: the case of pregnant Indonesian women. European journal of clinical nutrition, 57(5), 654.

Harvey, C. A., Rakotobe, Z. L., Rao, N. S., Dave, R., Razafimahatratra, H., Rabarijohn, R. H., ... \& MacKinnon, J. L. (2014). Extreme vulnerability of smallholder farmers to agricultural risks and climate change in Madagascar. Phil. Trans. R. Soc. B, 369(1639), 20130089.

Horton, S. (2001). The economics of nutritional interventions. In Nutrition and Health in Developing Countries (pp. 507-521). Humana Press, Totowa, NJ.

Horton, S., Shekar, M., \& Ajay, M. (2009). Scaling up nutrition: What will it cost?. The World Bank.

Huang, K. S., \& Gale, F. (2009). Food demand in China: income, quality, and nutrient effects. China Agricultural Economic Review, 1(4), 395-409.

Jamora, Nelissa. (2014). Price transmission in international rice markets. University of Göttingen.

Just, R. E., \& Pope, R. D. (1979). Production function estimation and related risk considerations. American Journal of Agricultural Economics, 61(2), 276-284.

Kusin, J. A., Kardjati, S., \& Sudibia, I. K. (1979). Nutrition and nutritional status of rural women in East Java. Tropical and geographical medicine, 31(4), 571-585.

Lorefält, B., Andersson, A., Wiréhn, A. B., \& Wilhelmsson, S. (2011). Nutritional status and health care costs for the elderly living in municipal residential homes-an intervention study. The journal of nutrition, health \& aging, 15(2), 92-97. 
Løvendal, C. R., \& Knowles, M. (2007). Tomorrow's hunger: A framework for analysing vulnerability to food security. Food Security: Indicators, Measurements, and the Impacts of Trade Openness, 62-94.

Mahmudiono, T., Sumarmi, S., \& Rosenkranz, R. R. (2016). Household dietary diversity and child stunting in East Java, Indonesia. Asia Pacific journal of clinical nutrition.

Malian, A. H., Mardianto, S., \& Ariani, M. (2016). Faktor-faktor yang mempengaruhi produksi, konsumsi dan harga beras serta inflasi bahan makanan. Jurnal Agro Ekonomi, 22(2), 119-146.

Martianto, D. (1999). Magnitude, Determinant, and Indicators of Household Food and Nutrition Security in RuralWestJavaand East Nusa Tenggara, Indonesia. Ph.D. Dissertation. University of the Philippines, los Banos.

Martianto, D. dan M. Ariani. (2001). Analisis Ketahanan Pangan di Indonesia. Jurusan Gizi Masyarakat dan Sumberdaya Keluarga Fakutas Pertanian, Institut Pertanian Bogor

Martorell, R. (1996). The role of nutrition in economic development. Nutrition Reviews, 54(4), S66-S71.

McCulloch*, N. (2008). Rice prices and poverty in Indonesia. Bulletin of Indonesian Economic Studies, 44(1), 45-64.

McCulloch, N., \& Peter Timmer, C. (2008). Rice policy in Indonesia: a special issue. Bulletin of Indonesian Economic Studies, 44(1), 33-44.

McDonald, P. (2014). A population projection for Indonesia, 2010-2035. Bulletin of Indonesian Economic Studies, 50(1), 123-129.

McNew, K. (1996). Spatial market integration: Definition, theory, and evidence. Agricultural and Resource Economics Review, 25(1), 1-11.

Meyer, J. (2004). Measuring market integration in the presence of transaction costs-a threshold vector error correction approach. Agricultural Economics, 31(2-3), 327-334.

Meyer, J., \& von Cramon-Taubadel, S. (2004). Asymmetric price transmission: a survey. Journal of agricultural economics, 55(3), 581-611.

Minot, N. (2014). Food price volatility in sub-Saharan Africa: Has it really increased?. Food Policy, 45, 45-56.

Minot, N. (2010). Transmission of world food price changes to markets in Sub-Saharan Africa. Washington: International Food Policy Research Institute. 
Morton, John F. (2007). The impact of climate change on smallholder and subsistence agriculture. Proceedings of the national academy of sciences 104.50): 19680-19685.

Nakelse, T., \& Ouedraogo, A. (2011). Food insecurity and vulnerability in rural Burkina Faso: An approach using a stereotype logistic regression model.

Peter Rosner, L., \& McCulloch, N. (2008). A note on rice production, consumption and import data in Indonesia. Bulletin of Indonesian Economic Studies, 44(1), 81-92.

Peltzman, S. (2000). Prices rise faster than they fall. Journal of political economy, 108(3), 466502.

Pinstrup-Andersen, P. (2009). Food security: definition and measurement. Food security, 1(1), 5-7.

Pradhan, M., Suryahadi, S., Sumarto, S., \& Printchett, L. (2000). Measurements of Poverty in Indonesia: 1996, 1999. and Beyond.

Prentice, A. M. (2005). The emerging epidemic of obesity in developing countries. International journal of epidemiology, 35(1), 93-99.

Quiroz, J. A., \& Soto, R. (1995). International Price Signals in Agricultural Markets: Do Governments Care?.

Radix A, I., Vadivel, V., Nohr, D., \& Konrad Biesalski, H. (2012). Dietary formulation to overcome micronutrient deficiency status in Indonesia. Nutrition \& Food Science, 42(5), 362-370.

Rae, A. N. (1999). Food consumption patterns and nutrition in urban Java households: the discriminatory power of some socioeconomic variables. Australian journal of agricultural and resource economics, 43(3), 359-383.

Rahmawati, W., Wirawan, N. N., Wilujeng, C. S., Fadhilah, E., Nugroho, F. A., Habibie, I. Y., ... \& Ventyaningsih, A. D. I. (2016). Gambaran Masalah Gizi pada 1000 HPK di Kota dan Kabupaten Malang (Illustration of Nutritional Problem in the First 1000 Days of Life in Both City and District of Malang, Indonesia). Indonesian Journal of Human Nutrition, 3(1), 20-31.

Rapsomanikis, G., Hallam, D., \& Conforti, P. (2006). Market integration and price transmission in selected food and cash crop markets of developing countries: review and applications. Agricultural Commodity Markets and Trade, 187-217.

Ravallion, M. (1990). Income effects on undernutrition. Economic development and cultural change, 38(3), 489-515.

Roberts, J. M., Stockton, D. J., \& Struckmeyer, C. S. (1994). Evidence on the Flexibility of Prices. The Review of Economics and Statistics, 142-150. 
Scaramozzino, P. (2006). Measuring vulnerability to food insecurity. ESAWorking Paper, (612).

Schultz, T. P. (2005). Productive benefits of health: Evidence from low-income countries. Health and Economic Growth: Findings and Policy Implications. MIT Press, Cambridge MA, 257-286.

Sharma, R. (2003). The transmission of world price signals: the concept, issues, and some evidence from Asian cereal markets. Agricultural Trade and Poverty: Making Policy Analysis Count, 141-160.

Skoufias, E., Tiwari, S., \& Zaman, H. (2011). Can we rely on cash transfers to protect dietary diversity during food crises? Estimates from Indonesia. The World Bank.

Slayton, T. (2009). Rice crisis forensics: How Asian governments carelessly set the world rice market on fire.

Soekarjo, D. D., De Pee, S., Kusin, J. A., Schreurs, W. H. P., Schultink, W., \& Bloem, M. W. (2004). Effectiveness of weekly vitamin A (10000 IU) and iron (60 mg) supplementation for adolescent boys and girls through schools in rural and urban East Java, Indonesia. European journal of clinical nutrition, 58(6), 927.

Statistics Indonesia. (2002). Statistik Indonesia 2002 annual yearbook. Statistics Indonesia. https://www.bps.go.id/publication/2003/05/15/349dc89e726424d7e00d5078/statist ik-indonesia-2002.html

Statistics Indonesia. (2010). Laju Pertumbuhan Penduduk Menurut Provinsi. Statistics Indonesia. https://www.bps.go.id/statictable/2009/02/20/1268/laju-pertumbuhanpenduduk-menurut-provinsi.html

Statistics Indonesia. (2015). Jumlah Penduduk Miskin, Persentase Penduduk Miskin dan Garis Kemiskinan, 1970-2013. Statistics Indonesia. https://www.bps.go.id/statictable/2009/02/20/1268/laju-pertumbuhan-pendudukmenurut-provinsi.html

Statistics Indonesia. (2017). Perkembangan indeks kedalaman kemiskinan p1 menurutkabupaten kota di provinsi jawa timur tahun 2012--2017. Statistics Indonesia. https://jatim.bps.go.id/statictable/2018/01/30/756/perkembangan-indekskedalaman-kemiskinan-p1-menurut-kabupaten-kota-di-provinsi-jawa-timur-tahun$\underline{\text { 2012---2017.html }}$

Statistics Indonesia. (2018). Statistik Indonesia 2018 annual yearbook. Statistics Indonesia. https://www.bps.go.id/publication/2018/07/03/5a963c1ea9b0fed6497d0845/statisti k-indonesia-2018.html 
Strauss, John, and Duncan Thomas. (1998). Health, nutrition, and economic development. Journal of economic literature 36.2: 766-817.

Tian, X., \& Yu, X. (2012). The Demand for Nutrients in China: A Direct Approach. In 2012 Conference, August 18-24, 2012, Foz do Iguacu, Brazil (No. 126325). International Association of Agricultural Economists.

Tifaoui, S., \& von Cramon-Taubadel, S. (2017). Temporary sales prices and asymmetric price transmission. Agribusiness, 33(1), 85-97.

Valliant, Melinda W., et al. (2012). Nutrition education by a registered dietitian improves dietary intake and nutrition knowledge of a NCAA female volleyball team. Nutrients 4.6: 506-516.

Von Cramon-Taubadel, S., \& Meyer, J. (2000). Asymmetric price transmission: Fact or artefact?. Institut für Agrarökonomie der Universität Göttingen.

Von Cramon-Taubadel, S. (1998). Estimating asymmetric price transmission with the error correction representation: An application to the German pork market. European review of agricultural economics, 25(1), 1-18.

Warr, P. (2008). The transmission of import prices to domestic prices: an application to Indonesia. Applied Economics Letters, 15(7), 499-503.

Widarjono, A., \& Rucbha, S. M. (2016). Household Food Demand in Indonesia: a Two-stage Budgeting Approach. Journal of Indonesian Economy and Business, 31(2), 163-177.

Widiarsih, D. (2013). Pengaruh sektor komoditi beras terhadap inflasi bahan makanan. Jurnal Sosial Ekonomi Pembangunan, 2(6).

Wondemu, K. (2015). Price transmission asymmetry in spatial grain markets in Ethiopia. African Development Review, 27(2), 106-116.

World Bank. (2018). The World Bank in Indonesia. World Bank

World Food Programme. (2014). 10 Facts about Malnutrition in Indonesia. https://www.wfp.org/stories/10-facts-about-malnutrition-indonesia. (accessed 3 June 2016).

Zhou, D., \& Yu, X. (2014). Calorie elasticities with income dynamics: evidence from the literature. Applied Economic Perspectives and Policy, 37(4), 575-601. 


\title{
CURRICULUM VITAE
}

\author{
FARAH WULANDARI PANGESTUTY \\ Address: $\quad$ Heinrich-Düker Weg 1237073 Göttingen, Germany \\ Telephome: $\quad$ +495513920214 \\ Email: $\quad$ fpanges@gwdg.de \\ Date of birth: $\quad 23^{\text {rd }}$ April 1982 \\ Place of birth: $\quad$ Malang, Indonesia
}

\section{CURRENT POSITION}

11/2014 - present Ph.D. Candidate in Agriculture Economics and Rural Development RTG 1666: GlobalFood "Transformation of Global Agri-Food System" University of Göttingen, Germany

\section{EDUCATION}

$\begin{array}{ll}2004-2008 & \begin{array}{l}\text { Master of Economics } \\ \text { University of Brawijaya Indonesia }\end{array} \\ 2000-2004 & \begin{array}{l}\text { Bachelor of Economics and Development Studies } \\ \text { University of Brawijaya Indonesia }\end{array}\end{array}$

CONFERENCE PRESENTATION

May, 2017

Undernoutrition Vulnerability Analysis in Indonesia

The paper presented in the $22^{\text {nd }}$ EBES Conference held in Rome - Italy 